\title{
Post-Colonial Institutions in Central America
}

\begin{abstract}
Why do otherwise very similar states develop different institutions? I investigate the determinants of state institutions using process tracing in five Central American states to uncover the causal mechanisms operating during post-colonial state building. I demonstrate that elite conflict drives the origins and persistence of institutions. Elite conflict has a differential impact on the information transmitted to rulers regarding the extent of their political power and forms preferences over institutions. This research uses processing tracing because it allows for a more fine grained within-case analysis on the origins of institutions and the validation of causal mechanisms than other methods.
\end{abstract}

\author{
Andrew Fogarty \\ University of Virginia \\ apf2bb@virginia.edu
}

23 April 2017 


\section{Introduction}

"Nothing exists but our misfortune. Our blind experience encourages miserable caudillos and localism, in which one man fights another, one family opposes another, one town attacks another, all with such variety of different interests that we will never be able to form a state" ${ }^{1}$ - a Nicaraguan ministerial report in 1853

Why do otherwise very similar states develop different institutions? Existing accounts assume that the origins of institutions are largely guided by human capital, or by geographic endowments such as natural resources, or by a colonizer's settlement policies which seemingly eliminates the need to study this question. ${ }^{2}$ I challenge this view by arguing that the origins and persistence of institutions are instead a consequence of elite conflict. ${ }^{3}$ I contend that diverse preferences among local elites who ruled city-state like municipalities, exacerbated by the collapse of Spanish power through Napoleon, belligerently promoted local autonomy and resisted national and supranational authority. The number of colonial municipalities, each with its own interests, had a differential impact on the scale of elite conflict which produced asymmetries in the origins and types of institutions found in post-independence Central America.

To test this argument, this paper uses process tracing to analyze five Central American countries. ${ }^{4}$ Central America is an ideal setting to test this argument for several reasons. First, given the length of time since independence and the broad similarities across the five republics, the region offers an exceptional opportunity to explore historical-

\footnotetext{
${ }^{1}$ (Burns 1991, 34)

${ }^{2}$ (Acemoglu et al. 2002; Gallup et al. 1999; Glaeser et al. 2004; Mahoney 2010)

3 "Institutions are the humanly devised constraints that structure political, economic and social interaction. They consist of both informal constraints (sanctions, taboos, customs, traditions, and codes of conduct), and formal rules (constitutions, laws, property rights)." (North 1991, 97)

${ }^{4}$ Belize and Panama had little political interaction with the Central American states up until the mid 1950s. Panama was a province of the viceroyalty of New Granada and became part of the republic of Gran Colombia while Belize was a British colony. Thus, the region of Central America is limited to those five countries that until 1821 made up the Captaincy General of Guatemala and achieved independence under the name of the United Provinces of Central America. (Perez-Brignoli 1989, 7)
} 
institutional development while minimizing potential omitted variable bias. Second, a small $n$ comparison allows for thinking about the effect of colonialism and institutions on development in a different light. Instead of pondering why Central America is different from the rest of the world, this study considers why Central American states emerged so different from each other when existing accounts predict that they should not. Third, the presence of prospective exogenous variables from the colonial era provides an opportunity to mitigate endogenous threats which complicate institutional analysis. The image below of per capita income (which is highly correlated with institutions) is used as a simple measure to illustrate the persistent long-run differences among Central American states.

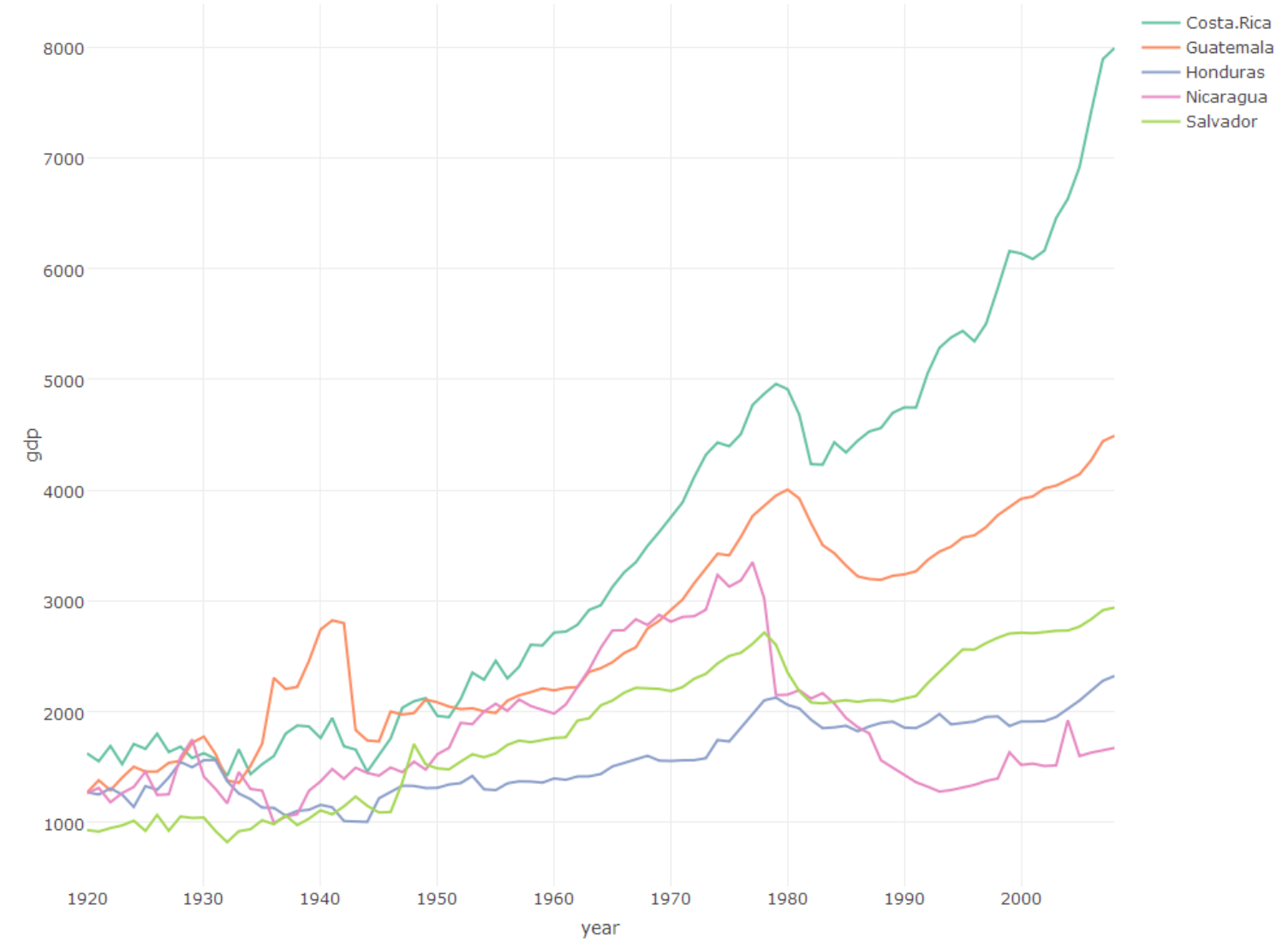

Figure 1: GDP per Capita - 1990 GK Dollar (Maddison 2013)

Two main finding emerge from this research. First, there is clear evidence that the scale 
of elite conflict during post-colonial state building in Central America had a differential effect on post-colonial institutions. Second, I find little support for alternative explanations which promote geographical endowments, settlement feasibility, export agriculture, or ruler ideology in explaining Central America's institutions. Taken collectively, these findings suggest that a new approach, one that incorporates historical institutionalism and rational choice, is necessary to improve existing theories on the origins of institutions.

This analysis proceeds in four major parts. First, it critically analyzes the competing explanations for my dependent variable (institutions) and my independent variable (elite conflict). I show how current theories cannot adequately explain the institutional variation that we see within Central America. Second, I outline a new theory to explain the origins of institutions in state building. Third, I test the theory's logic and causal mechanisms in a series of five case studies on Central American states since independence. Fourth, I conclude the analysis by re-evaluating the theory and highlighting the implications and contribution of this research.

\section{Literature Review}

The competing explanations for my dependent variable, institutions, fall into three broad categories: geography, colonial institutions, and Central American specific factors. The most influential and important contributions to this topic are general theories which seek explanations for why places like Central America are different from the United States and Europe. As with any general theory, some specificity is lost in exchange for generalization, yet it is the generality which fails to predict institutional outcomes in Central America. In this section, I summarize some of the most relevant competing theories and argue why they cannot explain post-colonial institutions in Central America. 


\subsection{Geography}

Geography is a powerful exogenous explanation which temporally precedes all other competing explanations among states. A measure as simple as the distance between the state and the equator performs remarkably well in explaining long term economic outcomes. ${ }^{5}$ A state's geography serves as a strong predictor of its climate, access to natural resources, transportation costs, prevalence of disease, and even institutions. ${ }^{6} \mathrm{My}$ argument departs from this literature broadly over its inability to overrule institutions or to explain institutional variation in Central America. ${ }^{7}$ The five Central American republics effectively share the same climate, soil, access to sea, and natural resource distribution and yet they have different institutions. Since geography is constant in this setting, it surely cannot be playing a causal role in explaining Central America's institutional variation.

\subsection{Colonialism and Institutions}

Several general theories on colonialism and post-colonial institutions have emerged which argue that post-colonial institutions are a consequence of a colonizer's survival, indigenous population densities, or colonizer ideology. ${ }^{9}$ While immensely influential, Acemoglu et al. (2001 and 2002) and Mahoney's general theory fail to explain Central America's institutional outcomes primarily because it is unclear what the theory predicts for Central American states. Even if we are to believe that settlement survivability or population density explained the predominant type of institutions selected by colonizers, Central America sits in an unclear middle ground given the theory. The isthmus certainly had extractive institutions, particularly centered on forced Indian tribute during the

\footnotetext{
${ }^{5}$ (Rodrik et al. 2004, 2)

${ }^{6}$ (Gallup at al. 1999, 9)

${ }^{7}$ (Easterly and Levine 2002, 32; Rodrik et al. 2004, 5; Sokoloff 2000, 4)

${ }^{8} \mathrm{~A}$ wide variety of large $\mathrm{n}$ statistical analysis collectively find that after controlling for institutions, geography has little independent explanatory power, but of course remains an important factor.

${ }^{9}$ (Acemoglu et al. 2001, 1370; Acemoglu et al. 2002, 1235; Mahoney 2010, 26)
} 
Hapsburg Monarchy, but it also had some protective institutions such as the rule of law and property rights (if the Crown awarded land). ${ }^{10}$ Similarly, by arguing that Spain's transition from mercantilist to liberal policies during colonialism had opposite effects on post-colonial development, Mahoney's general theory makes it difficult to explain the divergence of Central American institutions given their similar colonial experiences. ${ }^{11}$

\subsection{Export Agriculture}

A number of studies argue to some degree that the institutional and development outcomes that we see in Central America today are due to the ability of states to harness and proliferate valuable export agriculture, namely coffee and bananas. ${ }^{12}$ The logic here is that elites used the state to produce land tenure patterns and labor repressive institutions conducive to large scale agro-export production. With new exports exceeding traditional exports, elites unified, ceased intra-elite conflict, and used state power across the isthmus to their benefit. ${ }^{13} 14$ While the rise of new export agriculture was indeed important, it cannot completely explain the institutional variation in Central America for one very large reason. If coffee and bananas are a large predictor of institutions, then Guatemala, El Salvador, Nicaragua, and Honduras should be much more like Costa Rica yet they could not be further apart. ${ }^{15}$

\footnotetext{
${ }^{10}$ (Wortman 1982, 69; 112)

11 (Mahoney 2010, 32)

${ }^{12}$ (Jonas 1991; Perez-Brignoli 1989; Torres-Rivas 1993)

${ }^{13}$ (Bulmer-Thomas 1987, 18; Paige 1998; Williams 1994)

${ }^{14}$ The new exports are products like coffee and bananas while traditional exports were items like cochineal dye, indigo dye, cattle, and minerals.

${ }^{15}$ Costa Rica was the first to transition to coffee and is the richest, most free, and politically developed country within Central America. While being a first mover to new export agriculture was helpful, there is little reason to suspect it is playing a causal role in the institutional differences between states.
} 


\subsection{Ideology}

Another common explanation for the institutional and development outcomes in Central America is ideology. ${ }^{16}$ Following Central America's independence, elite conflict is argued to have been waged on liberal versus conservative ideological grounds. This argument particularly centers on the timing and intensity of when liberals were able to implement their policies. The basic logic is that ideology formed ruler preferences over institutions. Liberals were allegedly far more in favor of economic development than conservatives and the relative conservative domination of the isthmus from 1839 to 1870 hindered economic growth to such an extent that an explosion of prosperity occurred once liberal rulers swept the isthmus in 1870. While ideology played some role in institutional development, it fails to explain Central America's variation in institutions for two reasons. First, several authors argue that the ideology story has suffered from a revisionist history by scholars sympathetic to the liberal dictators. In general, they argue that the economic preferences between the two ideologies are relatively the same, that some dictators could not have possibly been liberal, and that the introduction of important economic institutions such as banks predated liberal leadership. ${ }^{17}$ Second, the isthmus had two separate waves of relatively homogeneous ideology imbued within leaders. Conservatives generally ruled from 1839 to 1870 while liberals generally ruled from 1870 to 1945. If ideology is key to explaining Central America, then we should not see much variation in Central American institutions as they all experienced continuous liberal rule at roughly the same time. ${ }^{18}$

\footnotetext{
16 (Mahoney 2001)

${ }^{17}$ (Bulmer-Thomas 1987, 3; Perez-Brignoli 1989, 94; Woodward 1993, 229)

${ }^{18}$ One exception is of course Nicaragua which transitioned to liberal rule later and was invaded by the U.S. in 1912 resulting in a reversion of the liberal regime to a conservative one.
} 


\section{Theory}

The primary independent variable in this analysis is elite conflict. Elite conflict has been used by other scholars to explain a wide range of outcomes including authoritarian durability, democratic transitions, and institutions. ${ }^{19}$ In this section I briefly outline the general logic of elite conflict arguments used to explain institutions and why it cannot adequately explicate variation in Central America's institutions.

\subsection{Elite Conflict}

In general, the origins of institutions are often explained as the result of bargaining and conflict amongst social groups who have different bargaining power and interests. ${ }^{20}$ Waldner theorizes that institutional differences emerge from varying levels of elite conflict in mediated states. ${ }^{21} 22$ Under conditions of intense conflict, elites are forced to choose institutions which promote and retain political power. ${ }^{23}$ This compels elite factions to incorporate the masses through side payments and to promote institutions that maintain their political loyalties through rents. Under conditions of less intense conflict, the political constraints are far less pressing and elites have more freedom to implement institutions which are more conducive to long-term economic development. Thus enabling elites to maintain power with a narrow coalition that excludes the popular sector while selecting institutions that favor long term economic development. ${ }^{24}$

This paper builds on the first part of Waldner's theory, particularly the notion that elite conflict predicts the selection of institutions, but it does not incorporate his coalition mechanism, because it cannot connect elite conflict to institutional outcomes in Central

\footnotetext{
${ }^{19}$ (Slater 2010; Yashar 1997; Waldner 1999)

${ }^{20}$ (Boone 2003, 20; Levi 1989, 10)

${ }^{21}$ In mediated states, local elites perform many of the functions associated with states such as tax collection and military recruitment.

${ }^{22}$ (Waldner 1999, 22)

${ }^{23}$ (Waldner 1999, 33)

${ }^{24}$ (Waldner 1999, 37)
} 
America. ${ }^{25}$ Waldner's mechanism is incompatible with the Central American historical record as evidence of coalitions within Central American politics is quite rare until early to mid 20th century. ${ }^{26}$ Highly personalistic dictators, or caudillos, dominated the chief executive positions across the isthmus from 1821 until 1945 in some cases. Often self-proclaimed dictators for life, they severely constrained the influence of economic elites. $^{27}$

\subsection{The Argument}

The origins and persistence of institutions in state building arise from elite conflict which imbues certain preferences over institutions within rulers. ${ }^{28} \quad 29$ Elite conflict presents a dilemma as it shapes the political system and constrains rulers who otherwise have similar preferences into prioritizing different institutions. ${ }^{30} 31$ The dilemma is as follows: do rulers secure their own immediate political survival, or do they promote long-run economic performance and regime stability? ${ }^{33}$ In state building, we can think of rulers having a finite amount of resources and the ability to invest those resources into two general strategies: development ${ }^{34}$ and security. ${ }^{35}$ The state can pursue both policy options in any proportion, but the level of elite conflict constrains rulers in determining just how many resources are put into security over development institutions. After all,

\footnotetext{
${ }^{25}$ (Waldner 1999, 35)

${ }^{26}$ (Yashar 1997)

${ }^{27}$ The more recent scholarship on Central American now generally agrees that elites had far less control and influence over the state than previously claimed.

${ }^{28}$ State building refers to the transition from a colonial colony to a post-colonial state.

${ }^{29}$ The origins of this elite conflict is addressed in the sections below.

${ }^{30}$ (Waldner 1999, 3)

${ }^{31}$ This assumes that rulers seek to maximize revenue to achieve whatever their ends may be. ${ }^{32}$ By assuming that all rulers have similar interests, the state can be taken as a unitary actor allowing for a more focused analysis on the societal/structural sources of variation on institutional outcomes. (Boone 2003, 9)

${ }^{33}$ (Geddes 1994, 18)

${ }^{34}$ Development institutions and policies are those which generally increase revenue such as infrastructure, land privatization, private property rights, education, and bureaucracy.

${ }^{35}$ Security institutions and policies are those which generally cost revenue such as the army and police, but of course, can promote development through security.
} 
concerns over survival tend to trump all others. ${ }^{36}$ When elite conflict is high, rulers worry more about their immediate political survival and invest far more state resources into security over development institutions. When elite conflict is low, rulers fear overthrow far less and invest state resources far more into development over security institutions. Over time, these investment strategies help explain the origins and dominance of certain institutions in states.

The table below depicts the theory as a causal graph in a process tracing framework. The causal graph is designed to be estimated using statistical techniques (representing average treatment effects) and is composed of random variables linking colonial municipalities, to elite conflict, to institution outcomes. ${ }^{37}$ For simplicity, the random variables are treated as binary variables that are either true or false. ${ }^{38}$ This graph's function is to: "represent as fully as possible, the set of causal relationships that constitute the process being traced by within-case evidence." 39 "Two nodes connected by an arrow have this precise meaning: the parent node is a direct cause of its descendant such that an exogenous intervention on $\mathrm{X}$ will change the distribution of the descendant variable holding all other variables in the model fixed." ${ }^{40}$ To be clear, the causal graph below claims that a change in the antecedent condition (the number of colonial municipalities) changes the level of elite conflict and therefore alters a ruler's preferences over institutions while holding all other variables fixed. It also claims that the two graphs are the counterfactual to each other. The causal graph aids our understanding of the process in two ways. First, it clearly delineates the causal process which allows analysts to consider whether the hypothesized nodes of the graph are collectively sufficient to generate the outcome. Second, it depicts the location of the causal mechanisms that must be identified and confirmed even prior

\footnotetext{
${ }^{36}$ (Finnegan 1999, 50)

${ }^{37}$ (Waldner 2014, 131)

${ }^{38}$ (Waldner 2014, 131)

${ }^{39}$ (Waldner 2014, 131)

${ }^{40}$ (Waldner 2015, 247)
} 
to any case study work. ${ }^{41}$ Event-history maps are generated for each case study which represent the "specific realization of the causal graph's random variables within a given historical context". ${ }^{42}$ It is the event-history maps (which closely mirror the causal graph) that are the direct target of process tracing. The subsequent sections broadly detail the historical context of the variables and the logic of their respective mechanisms to situate the reader within Central America prior to the case studies.

Table 1: Causal Graph: Origins of Post-Colonial Institutions in Central America

\begin{tabular}{|c|c|c|c|c|c|}
\hline Country & Antecedent Condition & $\mathrm{M}_{1}$ & Cause & $\mathrm{M}_{2}$ & Effect \\
\hline Costa Rica & \begin{tabular}{|c|} 
Low number \\
colonial municipalities
\end{tabular} & $\underset{\text { Preferences }}{\stackrel{\text { Low Diverse }}{\longrightarrow}}$ & \begin{tabular}{|c|} 
Low levels \\
of elite conflict
\end{tabular} & $\underset{\text { Development Institutions }}{\stackrel{\text { Preferences Over }}{\longrightarrow}}$ & $\begin{array}{c}\text { Development } \\
\text { Institutions }\end{array}$ \\
\hline $\begin{array}{c}\text { Guatemala, } \\
\text { El Salvador, } \\
\text { Nicaragua, } \\
\text { Honduras }\end{array}$ & $\begin{array}{c}\text { High number } \\
\text { colonial municipalities }\end{array}$ & $\underset{\text { Preferences }}{\stackrel{\text { High Diverse }}{\longrightarrow}}$ & $\begin{array}{c}\text { High levels } \\
\text { of elite conflict }\end{array}$ & $\underset{\text { Security Institutions }}{\stackrel{\text { Preferences Over }}{\longrightarrow}}$ & \begin{tabular}{|c|} 
Security \\
Institutions
\end{tabular} \\
\hline
\end{tabular}

One of the few institutions that survived the transition across Central America from over three centuries of colonial rule to independence is the ayuntamiento, ${ }^{43}$ or municipal council. ${ }^{44}$ Municipal councils, situated within municipalities, represented the most basic form of local day-to-day government and administration during colonial and post-colonial rule functioning akin to autonomous city-states. Their responsibilities included: health, security, markets, tax collection, schools, hospital, roads, and public works. ${ }^{45}$

During colonial rule, the Spanish Crown ranked municipalities by status just as they did social classes and people. ${ }^{46}$ The most distinguished rank was city (ciudad), the second,

\footnotetext{
${ }^{41}$ (Waldner 2014, 131)

${ }^{42}$ (Waldner 2016, 15)

${ }^{43}$ Another name for municipal councils during this time period is cabildo.

44 (Munro 1918, 27)

${ }^{45}$ (Dym 2006, 111)

${ }^{46}$ (Elliott 2007, 148)
} 
town (villa), and the lowest, peasant village (pueblo). Pueblos were the rank reserved for Indian towns as they did not have the same status, rights, or privileges as a Spanish town. ${ }^{47}$ The primary reason people who lived in outlying or unincorporated areas vied for municipality status was that it enabled settlements to establish their own ayuntamiento which not only established local governance and legitimized rule over others, but it also served as a local political unit that could more easily lobby the Crown (see image below). ${ }^{48}$ 4950 Indian pueblos had municipal governments with many of the same positions as Spanish municipal councils except that Spaniards chose the leaders from among the existing Indian hereditary power structure..$^{51}$

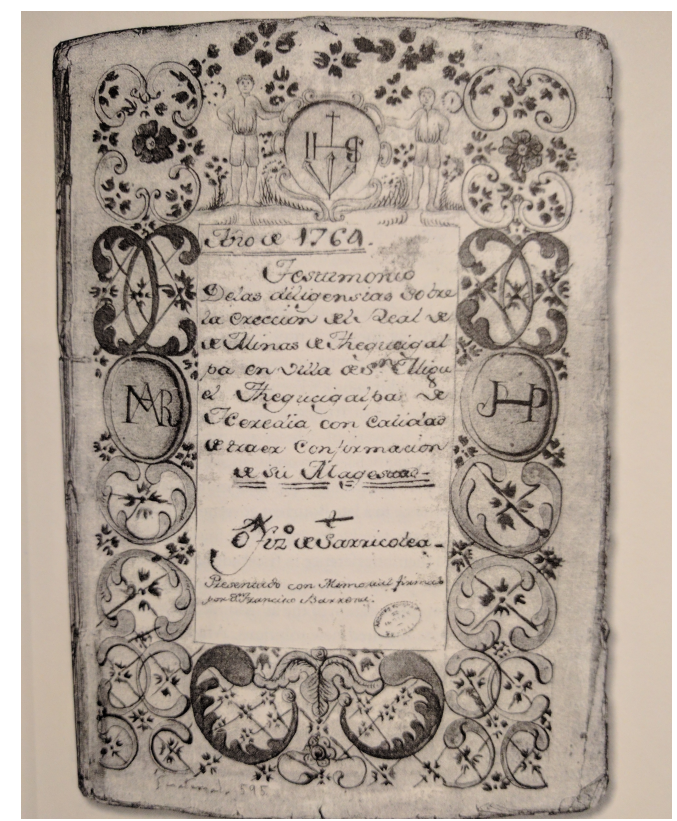

Figure 2: Royal Grant Authorizing a Villa in Honduras, 1768

Municipalities are measured by the number of royally granted cities, towns, and pueblos sanctioned by the Crown (see table below). Following independence, the nascent

\footnotetext{
47(Dym 2006, 18)

${ }^{48}$ (Dym 2006, 36)

${ }^{49}$ Obtaining royal sanction for city or town status often involved dispatching lobbyists to Madrid, constructing required government buildings, and making a donation to the Crown.

${ }^{50}$ Municipal council member positions were traditionally purchased or were inherited by descendants of the founding conquistadors. Towards the end of colonial rule, the council members were elected.

${ }^{51}$ (Dym 2006, 19)
} 
Central American republics assumed the authority to sanction city, town, and pueblo status individually and these numbers began to increase.

Table 2: Number of Cities, Towns, and Pueblos (Municipalities) as of 1824

\begin{tabular}{ccccc}
\hline Guatemala & Honduras & El Salvador & Nicaragua & Costa Rica \\
\hline 114 & 57 & 55 & 53 & 21 \\
\hline \multicolumn{5}{c}{ Dym 2006, 275 }
\end{tabular}

The distinction between low and high diverse preferences is a function of the number of colonial municipalities. As the number of municipalities increased, so did the extent of diverse preferences. From the 16th to the early 19th century, Central American municipal authorities did little to pursue their own sovereignty from the Spanish Crown. Instead, municipal authorities used the institution to achieve their interests within the imperial system. Yet when Napoleon Bonaparte invaded Spain in 1808 and severely disrupted Spain's political system, the subsequent vacuum in Spanish power provided the municipalities an opportunity to claim greater political authority and to advance their own local agendas. ${ }^{52} 53$ Over the next many decades, municipalities small and large behaved autonomously and often acted as if they needed no central approval for their actions. ${ }^{54}$ For instance, some municipalities seceded from their state, encouraged others to join them, proclaimed alliances with neighboring states (and municipalities), refused to acknowledge the existence of capitals, led rebellions, and routinely ignored legislation. ${ }^{55}$ Municipalities served their city or town's local interests first and the state's or other municipalities' interests only after deliberation. ${ }^{56}$ Even despite the existence of a nascent

\footnotetext{
${ }^{52}$ (Dym 2006, 66)

${ }^{53}$ Following King Ferdinand VII's abdication of the throne to Napeolon's brother Joseph, representatives from Central America's largest conquest cities participated in a new governing council located in one of the few cities not controlled by the French thanks to British warships, Cádiz. Despite their participation in forming a new constitutional monarchy which saw Ferdinand VII as the rightful ruler, Central America's delegates to Cádiz had yet to accept any form of sovereignty that superseded, rather than complimented, municipal authority. (Dym 2006, 126)

${ }^{54}$ (Dym 2006, 237)

${ }^{55}$ (Dym 2006, 190; McCreery 1994, 171)

${ }^{56}$ (Dym 2006, 236)
} 
state government, municipalities were the locus of political power for decades after independence. ${ }^{57}$ Put simply, collective action was far more difficult following Napoleon's invasion and especially after independence which followed thirteen years later. Collective action's difficulty was compounded by the number of colonial municipalities who each pursued local interests and were no longer constrained by the power of the Spanish Crown.

For over three centuries, no Spanish or creole armies ever faced each other in combat in Central America. ${ }^{58}$ Following independence from Spain, rival cities and towns across Central America waged near non-stop warfare for well over five decades. The table below provides a brief overview of this phenomenon in the near immediate aftermath of independence. While many towns could agree that they were independent of Spain and certainly of their neighboring republic, they could not agree on who would rule over them within their republic. Two attempts were made to unify Central America immediately after independence. The first was an attempt to join the Mexican Empire and the second was an attempt to mimic the federal model of the United States. Both attempts ultimately failed as rival towns across the isthmus engaged in decades of conflict either resisting or promoting the Mexican Empire and the Federation. Simultaneously, intense warfare occurred within all five provinces as rival cities fought each other for control of the chief executive and the location of the capital city. Many municipalities had preferences which were at odds with the provincial capital on issues of every size. Consequently, belligerent provincial capitals determined that they had the right to change a recalcitrant municipality's decision by force. These cleavages among others contributed to the instability across the isthmus. In this research, elite conflict is measured as the frequency of battles between municipalities or republics since independence. ${ }^{59}$

\footnotetext{
57 (Dym 2006, 160)

58 (Wortman 1982, 231)

${ }^{59}$ Although the intensity of the conflict (i.e., men killed) may be a better measure, such data is only available from 1824-1842.
} 
Table 3: Brief Overview of Elite Conflict: 1824-1842

\begin{tabular}{ccccc}
\hline Country & Battles & Men Killed & $\begin{array}{c}\text { Number of Chief } \\
\text { Executives }\end{array}$ & $\begin{array}{c}\text { Mean Survival } \\
\text { (months) }\end{array}$ \\
\hline Guatemala & 51 & 2291 & 18 & 12 \\
El Salvador & 40 & 2546 & 23 & 9.4 \\
Honduras & 27 & 682 & 20 & 10.8 \\
Nicaragua & 17 & 1203 & 18 & 12 \\
Costa Rica & 5 & 144 & 11 & 19.6 \\
\hline \multicolumn{5}{c}{ Marure 1895, 141-154 }
\end{tabular}

The turnover among chief executives, the severity, and the frequency of battles impressed upon Central American rulers specific information regarding the extent of their political power and formed their preferences over institutions. Elite conflict across the isthmus highlighted the dilemma rulers faced: do they secure their own immediate political survival or do they promote long-run economic performance and regime stability ${ }^{60}$ Given this dilemma, how do rulers allocate a finite amount of resources in states just emerging with almost none (and some sizable debt)? ${ }^{61}$

I argue that high levels of elite conflict impresses upon rulers preferences over institutions which favor their immediate political survival over the long-run economic interests of the state. Rulers direct relatively larger proportions of finite state resources towards the construction and maintenance of security institutions at the expense of those which favor economic development. Over time, the consequences of this strategy are numerable, but it primarily harms a state's long-run economic development and bureaucratic capacity as all other state interests are relatively neglected over immediate security concerns.

Alternatively, I argue that low levels of elite conflict impresses upon rulers preferences

\footnotetext{
${ }^{60}$ (Geddes 1994, 18)

${ }^{61}$ At independence in 1821, Honduras was in debt 5 million pesos. By 1888, Honduras was in so much debt that the entire country's land mass was estimated to be worth less than its debt. All other Central American republics faced similar situations. (Euraque 1972, 4)
} 
over institutions which favor the long-run economic interests of the state. When elite conflict is low, rulers face less overt opposition, fear overthrow far less, and consequently invest relatively larger proportions of finite state resources towards the construction and maintenance of development institutions at the expense of more powerful security institutions. Over time, the consequences of this strategy predict greater economic development and state bureaucratic capacity relative to comparable states that faced high levels of elite conflict.

This theory also supports dynamic change such that an exogenous intervention on elite conflict leads to changes in ruler preferences over institutions. While elite conflict remains high, spending on security institutions should remain the dominant investment made by rulers. In time periods where elite conflict is low, spending on economic and development institutions should become dominant.

The outcome being explained is the predominance of one general type of institution (security or development) over another. In Central America, militias were the common informal (army) security institution as formal armies generally did not emerge until the late 19th, early 20th century. In most cases, states expanded security institutions to include urban/rural police forces, rural judges, and auxiliary rural militias. Generally, the first significant development institution adopted by states was a Spanish and Italian organization named the Consulado de Comercio which was charged with essentially every task from creating roads to expanding agricultural settlements on the frontier. From there, states often expanded to other development institutions and policies such as schools, private property rights, public works bureaucracy, and land privatization.

Finally, it may be the case that the theory posed here quite easily works in the reverse. Elite conflict does not lead to the selection and emphasis of some institutions over others, but in fact, the institutions selected by rulers causes elite conflict. I pose several challenges to the reverse causality's position. First, the timing is simply incompatible 
with such an argument as the initial waves of elite conflict preceded the Central American republic's formation of individual governments and its rulers subsequent emphasis on institutions. Second, from the available time series government spending records, we can see that spending on military/non-military is dynamic and moves in response to conflict. $^{62}$ Third, I show how a significant portion of the conflict originated from the autonomous preferences of the colonial municipalities which also temporally preceded the formation of the independent Central American state.

\section{Hypotheses}

The hypotheses below formalize the statements made in the causal graph found in Table 1. The hypotheses are centered on demonstrating that each variable is sufficient to generate the next by way of the relevant mechanism. ${ }^{63}$

$H_{1}$ : Low diverse preferences links a sequence of events connecting a low number of colonial municipalities to low levels of elite conflict.

$\mathrm{H}_{2}$ : High diverse preferences links a sequence of events connecting a high number of colonial municipalities to high levels of elite conflict.

$\mathrm{H}_{3}$ : Preferences over development institutions links a sequence of events connecting low levels of elite conflict (a necessary condition) to rulers biasing the construction and maintenance of development institutions over security institutions.

$\mathrm{H}_{4}$ : Preferences over development institutions links a sequence of events connecting high levels of elite conflict (a necessary condition) to rulers biasing the construction and

\footnotetext{
${ }^{62}$ Despite very imperfect data, elite conflict and spending on security institutions is correlated for Guatemala, Costa Rica, and El Salvador respectively: 0.40, 0.13, 0.64.

${ }^{63}$ (Waldner 2014, 129)
} 
maintenance of security institutions over development institutions.

\section{Method and Data}

This paper tests the theory on all five Central American countries through process tracing. Process tracing is the "use of evidence from within a historical case to make inferences about causal explanations of that case". ${ }^{64}$ It involves providing evidence that each event as depicted in the subsequent event-history maps generates the next by the causal mechanism. ${ }^{65}$ Process tracing was selected over other analytical methods for three reasons. First, a sufficient amount of data is simply missing to generate enough statistical power to test this paper's theory. Second, this analysis is not intending to generalize across units which is one important goal of statistical modeling. Third, process tracing allows for a more fine grained within-case analysis of causal mechanisms and institutional origins in state building than other methods.

The time period under examination is independence from Spain (1821) until roughly the early 20th century. The duration of study is sufficiently long enough to capture the causal mechanisms in action because it incorporates the initial formation of the state as well as two distinct periods of conservative and liberal rule where most institutions arise. The data used in this analysis is almost entirely based on secondary sources from historians and political scientists, most of which extensively exploit primary documents. The amount and quality of evidence varies notably in this analysis as many historical records dating back to the 19th century in Central America have been lost through a combination of natural disasters, war, and carelessness. The first two cases, Guatemala and Costa Rica, have the most organized archives, the most preserved information, and therefore the most complete data. ${ }^{66}$ Despite the limitations, I argue that taken

\footnotetext{
${ }^{64}$ (Bennett and Checkel 2014, 2)

${ }^{65}$ (Waldner 2014, 132)

${ }^{66}$ This is partly why a large portion of the research on Central America tends to focus or emphasize these
} 
collectively, the available evidence sufficiently supports the theory and hypothesized causal mechanisms.

Another important aspect of this analysis is the counterfactual of the primary independent variable: elite conflict. Like a regression, this analysis centers on holding all other variables constant while changing the value of elite conflict to produce the variation in institutional outcomes. Costa Rica serves as a counterfactual to Guatemala, El Salvador, Honduras, and Nicaragua and vice versa. The claim is that had Guatemala et al. had low elite conflict, then their institutions would have been a lot more like Costa Rica. While counterfactuals are indeed difficult, the act of using the observed world to make claims about a hypothetical one, this claim is much stronger within the context of Central America given their near identical colonial (and post-colonial) experience, geography, climate, culture, and ethnic diversity which helps control for omitted variables. ${ }^{67}$

\section{Case Study: Costa Rica}

\subsection{Event History Map}

Mirroring the causal graph, the event-history map below depicts the process by which the events are traced in the case study.

Table 4: Event History Map: Costa Rica

\begin{tabular}{lcccc}
\hline Antecedent Condition & $\mathrm{M}_{1}$ & Cause & $\mathrm{M}_{2}$ & Effect \\
\hline $\begin{array}{c}21 \text { colonial } \\
\text { municipalities }\end{array}$ & $\stackrel{\text { Low Diverse }}{\text { Preferences }}$ & $\begin{array}{c}13 \text { battles } \\
\text { fought }\end{array}$ & $\stackrel{\text { Preferences Over }}{\text { Development Institutions }}$ & $\begin{array}{c}\text { Rulers predominantly invest } \\
\text { development institutions = TRUE }\end{array}$ \\
\hline $\begin{array}{l}\text { two cases. } \\
67 \text { (Przeworski 2004, 537) }\end{array}$ & &
\end{tabular}




\subsection{Expectations}

This paper's theory predicts that the extent of elite conflict leads rulers to be more likely to adopt certain types of institutions over others. The extent of elite conflict is determined by the number of royally granted municipalities during the colonial era. To support the argument, I need to show that the relatively small number of municipalities at the end of colonialism in Costa Rica leads to relatively low levels of elite conflict through the mechanism of diverse preferences. In the post-colonial period, municipalities should act in their own self interest and express their differences through words or belligerence. I also need to show that the low level of elite conflict leads rulers to invest more state resources into development institutions rather than security institutions. Over time, so long as the level of elite conflict remains low, we should see evidence that Costa Rica maintains its primary investment in development institutions while comparatively neglecting security institutions.

\subsection{Evidence}

The number of municipalities Costa Rica had entering the post-colonial era was relatively low. By 1824 (three years after independence from Spain), Costa Rica had 21 cities, towns, and pueblos formally sanctioned by the Spanish Crown. ${ }^{68} 69$ The image below depicts Costa Rica and some of its prominent cities and towns shortly after independence.

\footnotetext{
${ }^{68}$ (Dym 2006, 275)

${ }^{69}$ Due to available evidence, the exact number of royally granted settlements in 1821 is not available, but likely very close if not identical to the number presented here from 1824 .
} 


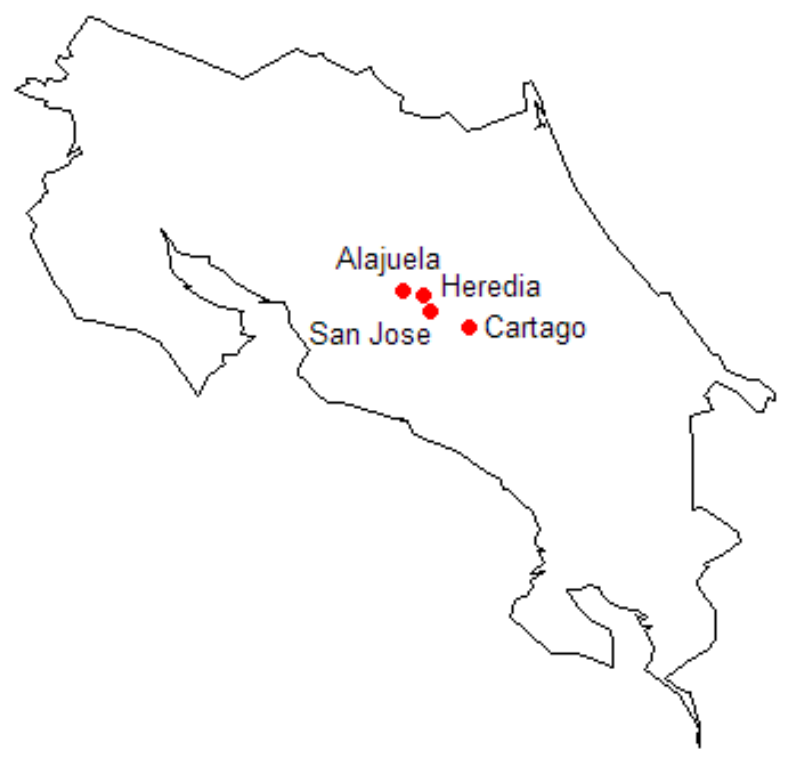

Figure 3: Costa Rica - Notable Settlements in 1821

Costa Rica's internal conflict was settled comparatively early as compared to its neighbors (see image below). The highpoint of (3) battles in 1856 is associated with Costa Rica's participation in the war against William Walker and the Filibusters in Nicaragua (discussed further below), while the few other battles were waged over the location of the capital city, state policy disagreements, and direct armed opposition to seize the capital. ${ }^{70}$ In 1823 shortly after Costa Rica's declaration of independence from Spain, the four largest towns (San José, Alajuela, Heredia, and Cartago) went to war over diverse preferences. Cartago and Heredia favored joining the Mexican Empire while San José and Alajuela opposed it. The victory of San José and Alajuela led to the transfer of the capital from the colonial conquest city of Cartago to San José. ${ }^{71}$ Following the internal

\footnotetext{
${ }^{70}$ (Dym 2006, 232)

${ }^{71}$ (Munro 1918, 144)
} 
collapse of the Mexican Empire, these same four large towns founded the early Costa Rican state comprised of a single chief executive whose location rotated among the four towns every three months (as no city could agree on a permanent capital). ${ }^{72}$ In 1835 , the chief executive Braulio Carrillo dismissed the rotational government and named San José as the permanent capital. This led to another war (War of the League) between the four largest towns as Cartago, Heredia, and Alajuela allied together against San José. ${ }^{73}$ San José won the war in 1839, solidified its role as the seat of government, and faced no further attempts to seize the capital through armed opposition. It would be over 100 years (1949) until the next civil war engulfed San José. ${ }^{74}$

\footnotetext{
${ }^{72}$ (Dym 2006, 213)

73 (Dym 2006, 232)

74 (Paige 1998, 146)
} 
3

$$
2.5
$$
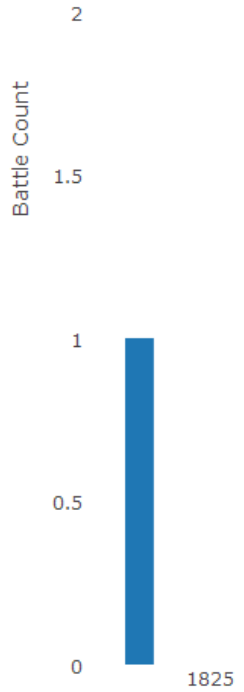
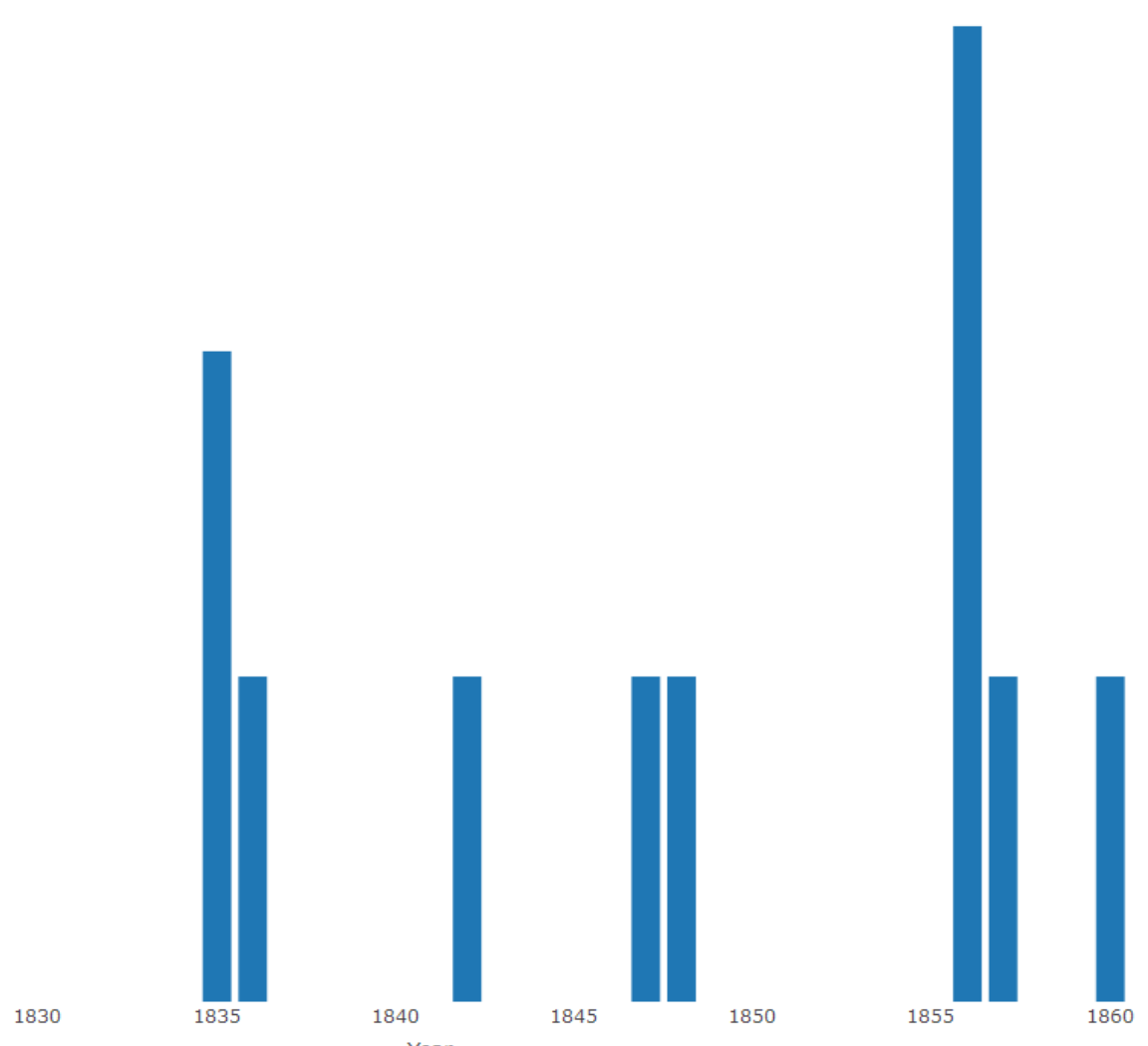

(Loría 1951; Marure 1895)

Carrillo and San José's victory in the War of the League against rival municipalities demonstrated that the capital was strong enough to stave off armed opposition from an alliance of the largest municipalities. Despite this achievement, the state had yet to build any political capacity. ${ }^{75}$ The discussion below provides strong evidence which follows in line with the theory's predictions: faced with comparatively little elite conflict, Costa Rica's rulers prioritized development institutions over security ones.

One of the first programs adopted by the San José government in the early 1820s was the provision of unused land for free or at little charge in exchange for growing ${ }^{75}$ (Mahoney 2001, 83) 
coffee for export on the frontier. In the early 1830s, national legislation was passed to reinforce and expand these efforts to other municipalities. ${ }^{76}$ From 1822 to 1839 , the state distributed and titled approximately 70,000 hectares of land which was nearly equivalent to the total amount of land distributed from 1584-1821. ${ }^{77}$ By 1848, Costa Rica became the first country in Central America to privatize all communal- and municipality- owned lands for purchase. ${ }^{78}$ The privatization of land favored small landholding which was based on existing family farm land-labor-tenure patterns. A land holding analysis from 1840-1935 shows that small estates dominated all coffee growing regions while prices and interest rates were low enough that even most poor could probably afford land. ${ }^{79}$

Carrillo (1838-42) and his successors prioritized increasing the state's revenue through monopolies on vice and spending on development institutions over security institutions. ${ }^{80} 81$ In 1841, Carrillo codified civil and criminal laws that guaranteed the protection of personal property rights and enforced contracts which played an important role in promoting state authority and increasing economic development. ${ }^{82}$ Additionally, a semi-private/state organization called La Sociedad Económica Itineraria (a sister organization roughly equivalent to the Consulado de Comercio) was created and charged with development of infrastructure and the expansion of agriculture in $1843 .{ }^{83}$

With respect to security institutions, Carrillo made a number of reforms. He reduced the size of the national militia by disbanding those stationed outside of San José, the area where elites would be most likely to launch armed opposition against him, but augmented

\footnotetext{
${ }^{76}$ Legislation often meant nothing as municipalities acted independently.

77(Mahoney 2001, 144)

${ }^{78}$ Many of the smaller municipalities ignored the law well into the 1850s.

${ }^{79}$ (Mahoney 2001, 145; Williams 1994, 45)

${ }^{80}$ (Carballo 1981, 97)

${ }^{81}$ Costa Rica, like all Central American states, controlled the sale of alcohol and tobacco which was one of the few ways in which the state made money aside from import and export taxes.

${ }^{82}$ (Mahoney 2001, 147)

${ }^{83}$ (Williams 1994, 47)
} 
rural and urban police forces. ${ }^{84} \quad 85$ He also instituted jefes politicos or department governors who had civil and military authority to collect taxes, to control local government expenditures, and to enforce laws across the country. ${ }^{86} 87$ The department governors acted as middle men between the municipalities who still held local power and the chief executive. Unlike other republics as we will see, Carrillo and his successors did not create a powerful army to coerce the population or safeguard their rule. ${ }^{88}$

Subsequent chief executives built on these policies instead of reversing them. Tomás Guardia (1870-1882) implemented a number of additional policies which kept the state focused more on development and less on coercive institutions. Guardia, who came to power via a coup, reformed the army by purging several senior leaders who held close ties with rival elites. ${ }^{89} 90 \mathrm{He}$ also increased the number of teachers and state bureaucrats by over $50 \%$ during his tenure and carried out more infrastructure projects from ports to roads to schools than any other previous regime. Costa Rica's literacy rate increased from $11 \%$ in 1864 to $31 \%$ in 1892 , and then $76 \%$ in $1927 .{ }^{91}$

The image and table below provides additional support for the narrative as it portrays Costa Rica's military spending (which includes all conflict years in this analysis) as a small proportion of overall total government spending (except during times of conflict).

\footnotetext{
${ }^{84}$ (Mahoney 2001, 147)

${ }^{85}$ The national militia was estimated to have less than 500 men.

${ }^{86}$ (Munro 1918, 37)

${ }^{87}$ A department is somewhat equivalent to a state in the U.S. Jefe politicos are an institution found throughout Central America.

${ }^{88}$ (Mahoney 2001, 148)

${ }^{89}$ (Mahoney 2001, 154)

${ }^{90}$ All Costa Rican presidents after 1889 were elected, served their full terms, and left at the end of office.

${ }^{91}$ (Mahoney 2001, 155)
} 


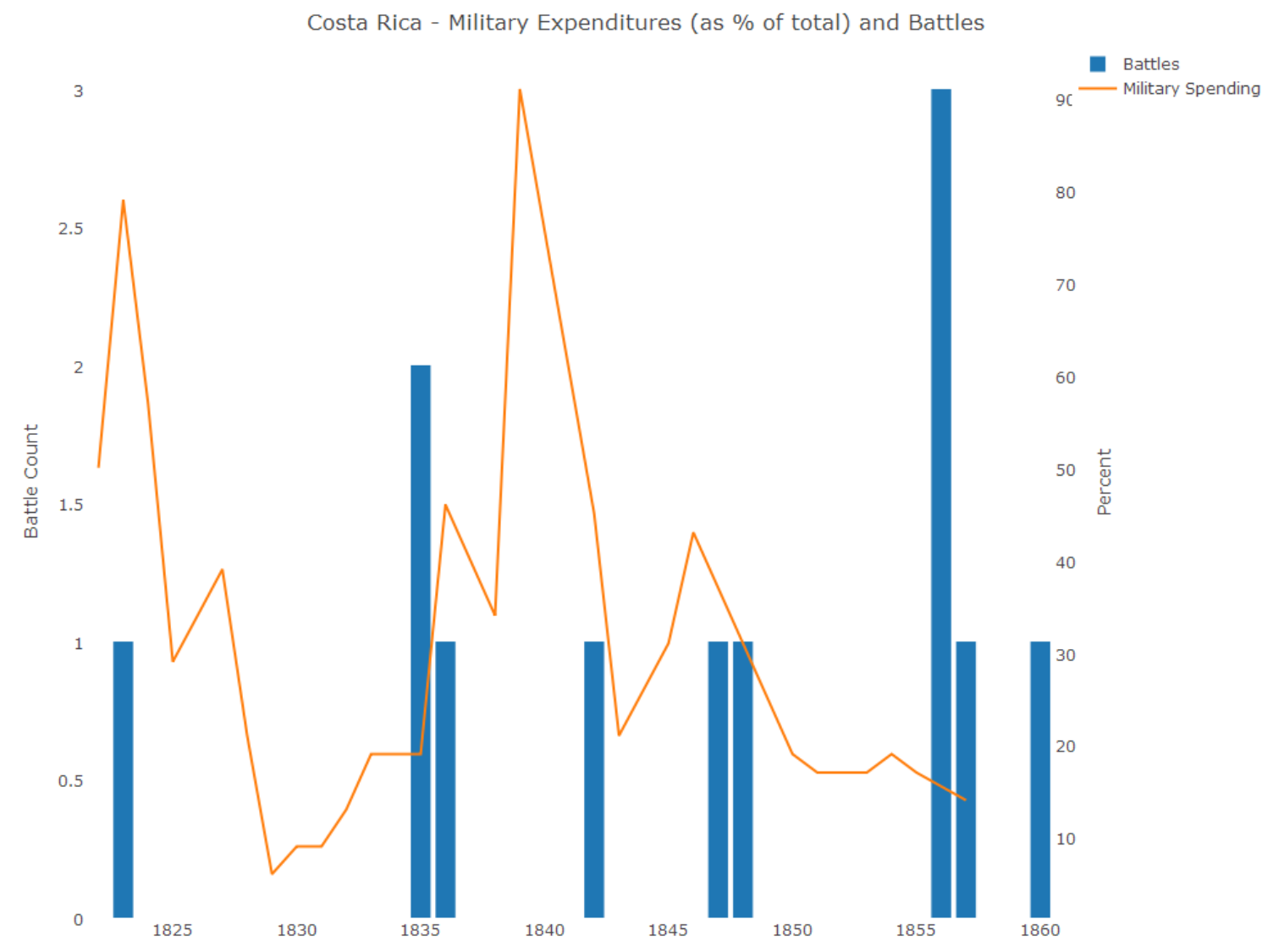

Figure 5: Costa Rica - Battles and Military Spending 
Table 5: Costa Rica: Military Expenditures as \% of Total 1821-1860

\begin{tabular}{|c|c|c|c|c|c|c|c|}
\hline Year & Military & Total & $\%$ & Year & Military & Total & $\%$ \\
\hline 1821 & 12 & 18 & 68 & 1838 & 17 & 50 & 34.2 \\
\hline 1822 & 6 & 13 & 50 & 1839 & 16 & 18 & 91 \\
\hline 1823 & 14 & 21 & 79 & 1842 & 49 & 109 & 45 \\
\hline 1824 & 13 & 23 & 57 & 1843 & 18 & 87 & 21 \\
\hline 1825 & 4 & 16 & 29 & 1845 & 31 & 101 & 31 \\
\hline 1826 & 13 & 47 & 34 & 1846 & 32 & 74 & 43 \\
\hline 1827 & 3 & 8 & 39 & 1848 & 58 & 186 & 31 \\
\hline 1828 & 8 & 38 & 21 & 1850 & - & 317 & 19 \\
\hline 1829 & 5 & 86 & 6 & 1851 & 55 & 315 & 17 \\
\hline 1830 & 7 & 88 & 9 & 1852 & 62 & - & - \\
\hline 1831 & 6 & 66 & 9 & 1853 & 78 & 457 & 17 \\
\hline 1832 & 6 & 44 & 13 & 1854 & 86 & 496 & 19 \\
\hline 1833 & 6 & 31 & 19 & 1855 & 88 & 532 & 17 \\
\hline 1834 & 6 & 30 & 19 & 1857 & 92 & 683 & 14 \\
\hline 1835 & 4 & 23 & 19 & 1859 & 109 & - & - \\
\hline 1836 & 14 & 30 & 46 & 1860 & 182 & - & - \\
\hline 1837 & 20 & 49 & 40 & & & & \\
\hline
\end{tabular}

This case study has shown evidence documenting the theorized mechanisms at work which links the sequence of events from the low number of colonial municipalities to the origins and emphasis on development institutions in Costa Rica. The strongest evidence for the first mechanism is the fact that municipalities went to war over their own preferences (i.e., Mexican annexation and control over the capital) and made alliances which lacked uniformity suggesting a low degree of diverse preferences. The strongest evidence for the second mechanism is time series government spending records and Carrillo's decision to reduce the state's militia a few years after winning the war against rival municipalities. A diminished threat from rival elites instilled preferences over institutions leading to a greater emphasis on development institutions which increased state revenue. Although Costa Rica is just the first piece of evidence, the subsequent cases act as counterfactuals to the primary independent variable (elite conflict) and serve to 
reinforce the points made by the theory.

\section{Case Study: Guatemala}

\subsection{Event History Map}

Mirroring the causal graph, the event-history map below depicts the process by which the events are traced in the case study.

Table 6: Event History Map: Guatemala

\begin{tabular}{|c|c|c|c|c|}
\hline Antecedent Condition & $\mathrm{M}_{1}$ & Cause & $\mathrm{M}_{2}$ & Effect \\
\hline $\begin{array}{l}114 \text { colonial } \\
\text { municipalities }\end{array}$ & $\underset{\text { Preferences }}{\stackrel{\text { High Diverse }}{\longrightarrow}}$ & $\begin{array}{c}92 \text { battles } \\
\text { fought }\end{array}$ & $\underset{\text { Security Institutions }}{\stackrel{\text { Preference Over }}{\longrightarrow}}$ & $\begin{array}{l}\text { Rulers predominantly invest } \\
\text { security institutions = TRUE }\end{array}$ \\
\hline
\end{tabular}

\subsection{Expectations}

This paper's theory predicts that the extent of elite conflict leads rulers to be more likely to adopt certain types of institutions over others. The extent of elite conflict is determined by the number of royally granted municipalities during the colonial era. To support the argument, I need to show that the relatively high number of municipalities at the end of colonialism in Guatemala generated relatively high levels of elite conflict through my mechanism of diverse preferences. Municipalities should behave autonomously and at times, quite belligerent. I also need to show that a high level of elite conflict leads rulers to invest more state resources into security institutions rather than development institutions. Over time, so long as the level of elite conflict remains high, we should see evidence that Guatemala invests mostly into security institutions while relatively neglecting development institutions. 


\subsection{Evidence}

Guatemala had the highest number of municipalities across the isthmus which is in part due to their position as the chief economic colony in the region. ${ }^{92}$ By 1824 (shortly after independence), there were 114 municipalities across the province. ${ }^{93}$ The image below depicts some of the most important settlements at independence.

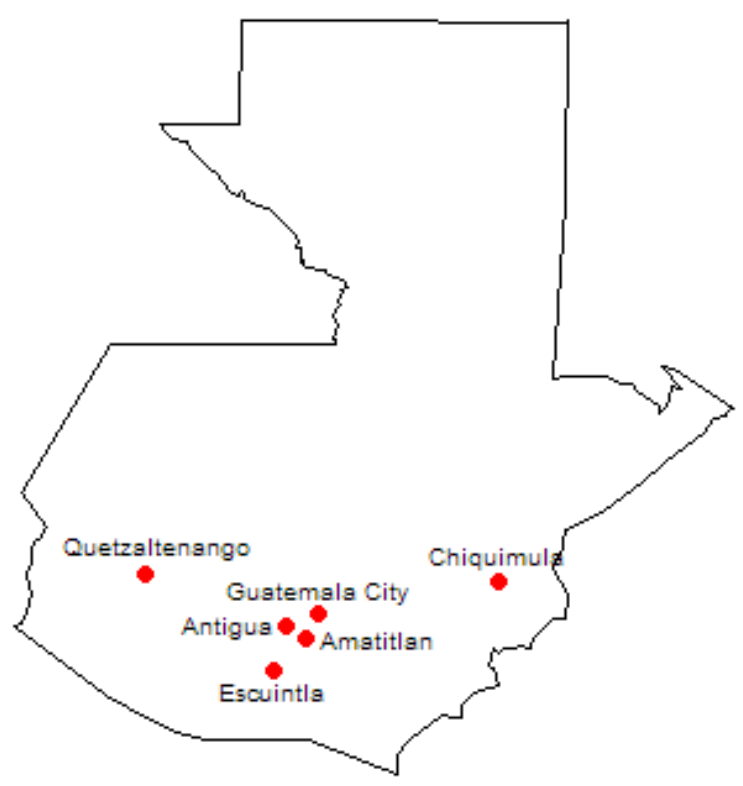

Figure 6: Guatemala - Notable Settlements in 1821

Elites in Guatemala fought incessantly over a wide range of issues for at least five decades (see image below). ${ }^{94}$ Within Guatemala some municipalities attempted secession,

\footnotetext{
${ }^{92} \mathrm{~A}$ significant amount of trade went through Guatemala to trade with the British at ports in either Honduras or Belize. Therefore it was advantageous for more merchants to reside in Guatemala than in Costa Rica.

${ }^{93}$ (Dym 2006, 275)

${ }^{94}$ I am missing data on Guatemala's involvement in internal and external conflicts after 1871. Additionally, the number battles represented after 1842 are a highly conservative as they are derived from historical narratives only.
} 
led guerrilla war against the state, and engaged in direct armed opposition to seize the capital. ${ }^{95}$ For instance, the Quetzaltenango municipality declared secession twice and fought battles with Guatemala City, once in early 1840 and again in late 1840. Towns across the eastern half of Guatemala (known as la montaña region) led a sustained rebellion for over a decade (late 1840s-50s). ${ }^{96}$ The municipality of Chiquimula seceded from Guatemala and led an armed opposition temporarily seizing the Caribbean port of Izabal as well as the municipality of Escuintila. ${ }^{97}$ Esquipulas, a municipality east of Chiquimula, defected and placed itself under the authority of a municipality in Nicaragua. When the state responded militarily to rebellious municipalities, additional revolts broke out in other areas as the Guatemalan military struggled to manage simultaneous uprisings. ${ }^{98}$

Outside of Guatemala's borders, the state was involved in a number of battles in every other country except for Costa Rica. The battles were fought for four primary reasons: (1) force recalcitrant states and municipalities to accept a federal union, (2) resist any attempt to form a federal union (seen as a liberal ideological goal), (3) depose rival chief executives (caudillos) who held a liberal ideology, and (4) destroy exiles and rebels who used neighboring state territory to launch invasions against the capital. ${ }^{99}$ The first two seem at odds with each other but they encompass two large and independent periods of time in Guatemala. The switch in state goals came with changes in chief executives from a liberal caudillo to a conservative caudillo. ${ }^{100}$

\footnotetext{
${ }^{95}$ (Woodward 1993, 192-220)

${ }^{96}$ (Woodward 1993, 226)

${ }^{97}$ (Woodward 1993, 210)

98 (Woodward 1993, 237)

${ }^{99}$ (Woodward 1993, 232)

100 (Woodward 1993, 32-123)
} 


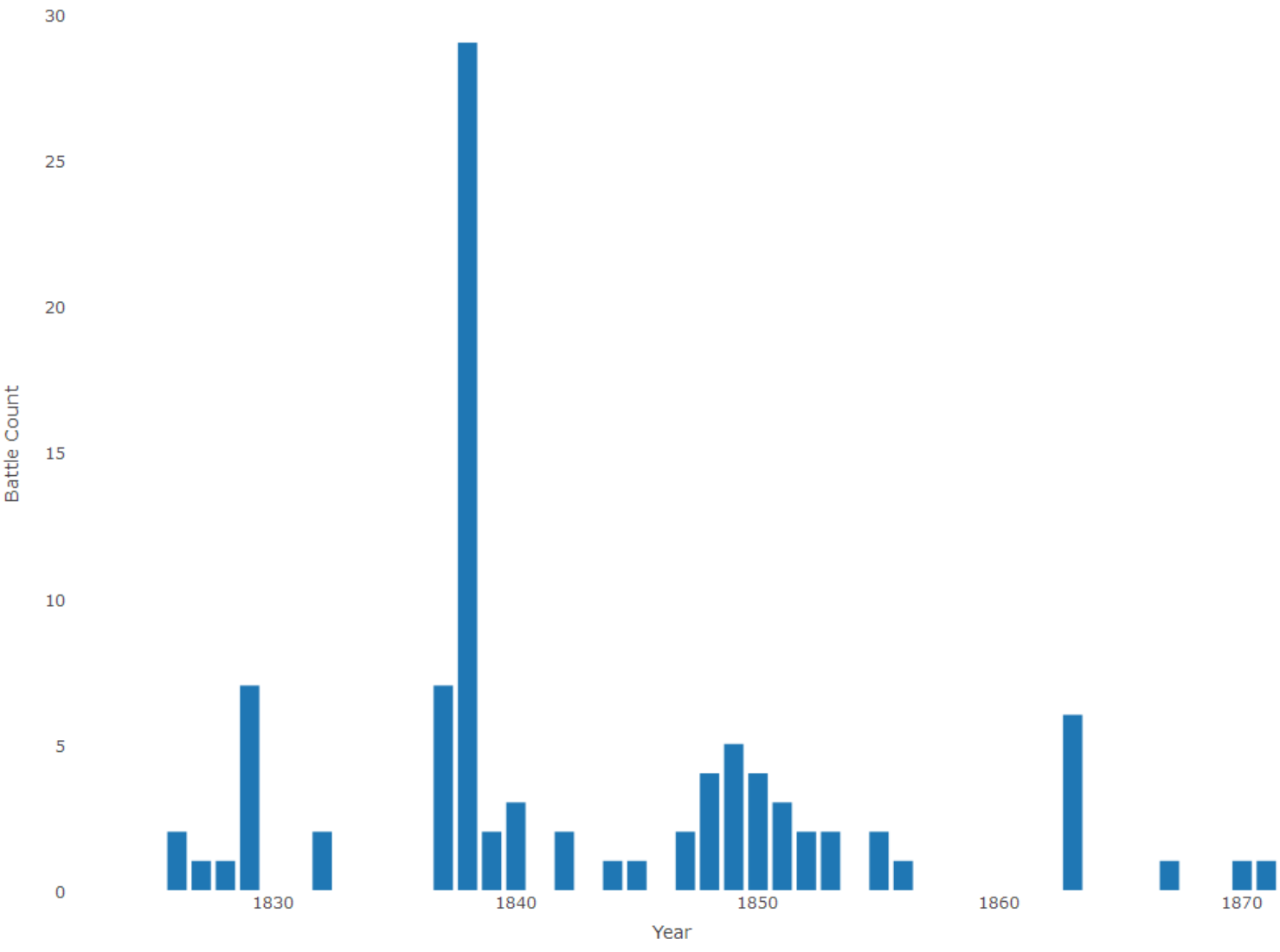

(Marure 1895; Woodward 1993)

Figure 7: Guatemala - Battles Fought Internally and Externally Since 1821

Following the failure of the federal republic which involved rapid turnover of chief executives, a conservative caudillo named Rafael Carrera seized power in 1839 and ruled until 1865. ${ }^{101}$ The extent of elite conflict facing Carrera placed a premium on building a state with a powerful military and security branches that could penetrate and secure the hinterlands. By the late 1840s, Guatemala's central government consisted of only a few ministers and an advisory council comprised of some of the Guatemalan economic elite. The legislature met once a year to pass recommended legislation and to hear reports on the government's progress. ${ }^{102}$ In stark contrast to Guatemala's small government, ${ }^{101}$ Carrera resigned and left the post on several occasions, only to return shortly thereafter. ${ }^{102}$ (Woodward 1993, 247) 
Carrera's army was the dominant state institution. By the late 1840s, Carrera's army grew enormously totaling 6,334 men and became the most powerful army on the isthmus. ${ }^{103}$ Carrera also used his military to help monitor the municipalities as he faced near continuous revolts in the western and eastern parts of the state. He placed loyal army officers in every department as mayors or (corregidores) who served as local dictators of their respective department. ${ }^{104} 105106$ The corregidores were intended to undermine municipality autonomy and were responsible for collecting taxes, directing public works, and maintaining law and order. The image below depicts Guatemalan state spending on security institutions and (a very conservative estimate of) battles fought which clearly demonstrates that the near continuous violence constrained rulers towards favoring security institutions over long term economic development.

\footnotetext{
103 (Woodward 1993, 251)

104 (Woodward 1993, 253)

${ }^{105}$ The state rarely admonished the department mayors despite complaints of their repressive policies.

${ }^{106}$ These positions were later renamed as jefes politicos.
} 


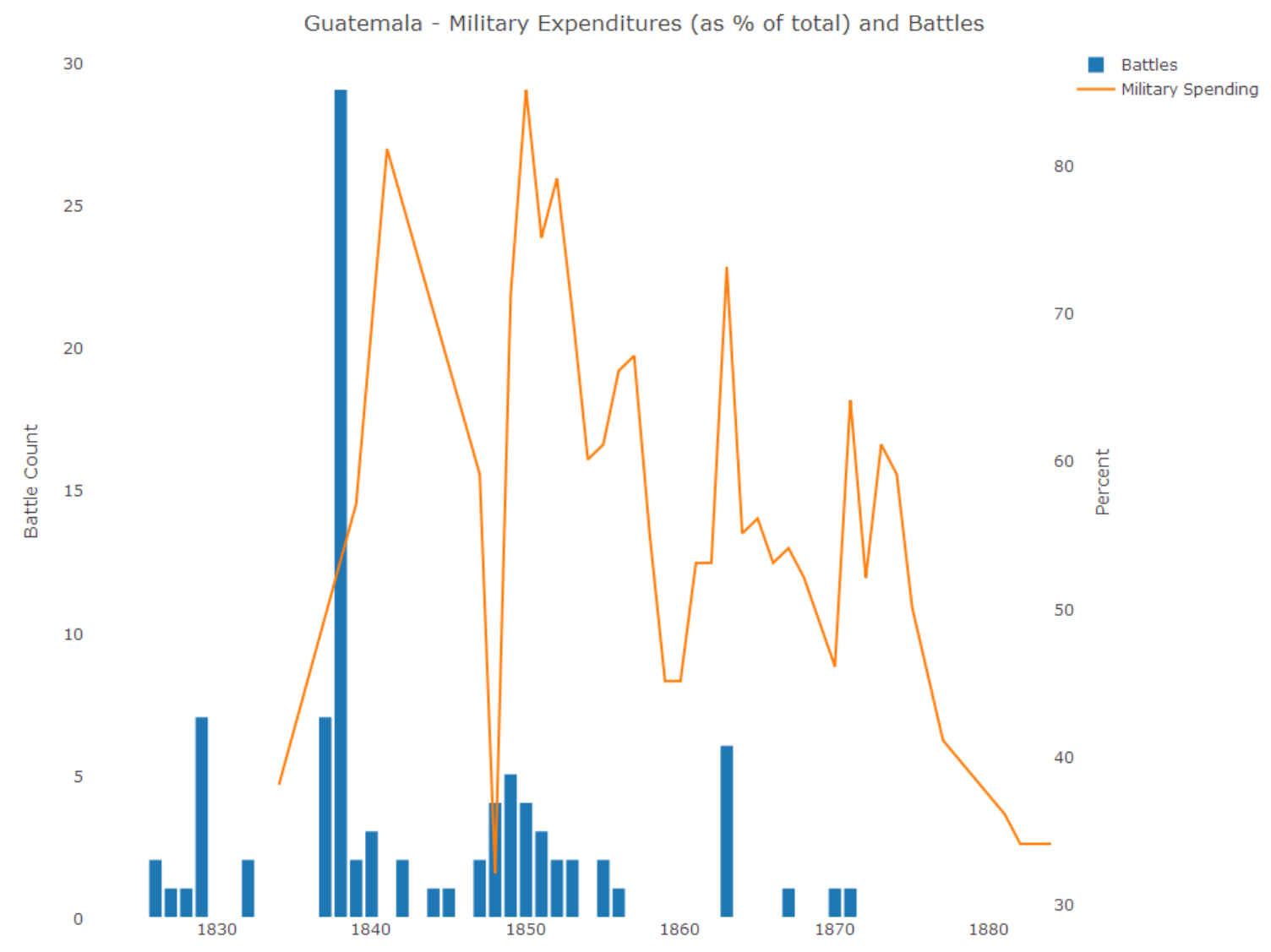

Figure 8: Guatemala - Battles and Military Spending Since 1821 
Table 7: Guatemala: Military Expenditures 1833-1883

\begin{tabular}{|c|c|c|c|c|c|c|c|}
\hline Year & Military & Total & $\%$ & Year & Military & Total & $\%$ \\
\hline $1833-34$ & 60 & 157 & 38 & 1862 & 248 & 464 & 53 \\
\hline $1838-39$ & 85 & 149 & 57 & 1863 & 527 & 724 & 73 \\
\hline $1839-40$ & 256 & 315 & 81 & 1864 & 278 & 510 & 55 \\
\hline $1841-42$ & 140 & 257 & 54 & 1865 & 246 & 436 & 56 \\
\hline $1846-47$ & 117 & 83 & 59 & 1866 & 248 & 464 & 53 \\
\hline $1847-48$ & 260 & 365 & 71 & 1867 & 282 & 522 & 54 \\
\hline $1848-49$ & 298 & 420 & 71 & 1868 & 210 & 406 & 52 \\
\hline $1849-50$ & 307 & 361 & 85 & 1869 & 293 & 597 & 49 \\
\hline $1851-52$ & 273 & 364 & 75 & 1870 & 366 & 791 & 46 \\
\hline 1852 & 230 & 292 & 79 & 1871 & 475 & 745 & 64 \\
\hline 1853 & 285 & 408 & 70 & 1872 & 771 & 1469 & 52 \\
\hline 1854 & 313 & 518 & 60 & 1873 & 1257 & 2062 & 61 \\
\hline 1855 & 293 & 482 & 61 & 1874 & 1019 & 1713 & 59 \\
\hline 1856 & 356 & 538 & 66 & 1875 & 297 & 589 & 50 \\
\hline 1857 & 386 & 580 & 67 & 1877 & 1072 & 2613 & 41 \\
\hline 1858 & 294 & 532 & 66 & 1881 & 323 & 885 & 36 \\
\hline 1859 & 231 & 515 & 45 & 1882 & 1164 & 3408 & 34 \\
\hline 1860 & 239 & 527 & 45 & 1883 & 1031 & 2997 & 34 \\
\hline 1861 & 246 & 461 & 53 & & & & \\
\hline
\end{tabular}

Although the military was the first priority, Carrera did place some emphasis on development institutions as civil disorder and war were a heavy burden on government finances. ${ }^{107}$ One of Carrera's first acts after seizing power in 1839 was reinstituting the Consulado de Comercio which was previously abolished by former liberal chief executives. ${ }^{108}$ The Consulado was a semi-private institution that was charged with the protection and development of commerce, infrastructure, and settlements by all possible means. ${ }^{109}$ 110 From 1840 to the late 1850s, Carrera and the Consulado built and improved hundreds

\footnotetext{
${ }^{107}$ (Woodward 1993, 408)

${ }^{108}$ The Consulado de Comercio was in essence a merchant guild patterned after similar guilds in Italy and Spain in the 14th century which coordinated commerce and enforced commercial laws.

${ }^{109}$ (Woodward 1966, 15)

${ }^{110}$ Guatemalan merchants lobbied the Spanish Crown for years in hope of establishing their own Consulado de Comercio. When they were granted the authority, it served as a merchant guild for the entire isthmus until independence.
} 
of kilometers of roads connecting municipalities to ports on the Caribbean and Pacific. ${ }^{111}$ Despite the apparent achievement, much of the infrastructure only reinforced existing commerce monopolized by Guatemala City merchants. The Consulado refused some development projects for municipalities located on the periphery as they feared rivals might challenge their control over commerce. ${ }^{112}$ Despite the Consulado's utility in furthering some infrastructure and economic development, Carrera left the provision of other public goods such as hospitals and education to the Catholic Church while his successor followed in close suit, questioning the logic of educating the Indian population. ${ }^{113}$

\subsection{Conclusion}

This case study has shown evidence documenting the theorized mechanisms at work which links the sequence of events from the high number of colonial municipalities to the origins and emphasis on security institutions in Guatemala. The strongest evidence for the first mechanism is the fact that municipalities led multi-year rebellions, seceded from Guatemala, and declared allegiance to neighboring republics for decades with no clear uniformity suggesting a high degree of diverse preferences. The strongest evidence for the second mechanism is time series government spending records, Carrera's government composition (i.e., a few ministers and a legislature that met once a year), and the creation of the largest militia on the isthmus. A continuous threat from rival elites increased Guatemalan rulers' uncertainty over their own political survival and imbued new preferences over institutions such that their spending of state resources heavily biased security over development institutions. ${ }^{114}$

\footnotetext{
${ }^{111}$ (Woodward 1993, 363)

${ }^{112}$ (Woodward 1993, 359)

113 (Bulmer-Thomas 1987, 20; Williams 1994, 54)

${ }^{114}$ Carrera lost control of the capital, Guatemala City, temporarily on three occasions in 1839, 1840, and 1845. (Woodward 1993, 96; 121; 173)
} 


\section{Case Study: El Salvador}

\subsection{Event History Map}

Mirroring the causal graph, the event-history map below depicts the process by which the events are traced in the case study.

Table 8: Event History Map: El Salvador

\begin{tabular}{|c|c|c|c|c|}
\hline Antecedent Condition & $\mathrm{M}_{1}$ & Cause & $\mathrm{M}_{2}$ & Effect \\
\hline \begin{tabular}{|c|}
55 colonial \\
municipalities
\end{tabular} & $\underset{\text { Preferences }}{\stackrel{\text { High Diverse }}{\longrightarrow}}$ & $\begin{array}{l}128 \text { battles } \\
\text { fought }\end{array}$ & $\stackrel{\text { Preferences Over }}{\stackrel{\text { Security Institutions }}{\longrightarrow}}$ & $\begin{array}{l}\text { Rulers predominantly invest } \\
\text { security institutions = TRUE }\end{array}$ \\
\hline
\end{tabular}

\subsection{Expectations}

This paper's theory predicts that the extent of elite conflict leads rulers to be more likely to adopt certain types of institutions over others. The extent of elite conflict is determined by the number of royally granted municipalities during the colonial era. To support the argument, I need to show that the relatively high number of colonial municipalities in El Salvador lead to the relatively high levels of elite conflict through my mechanism of diverse preferences. In the post-colonial period, municipalities should behave autonomously and at times, quite belligerent. I also need to show that the high level of elite conflict leads rulers to invest far more state resources into security institutions relative to development institutions. Over time, so long as the level of elite conflict remains high, we should see this pattern persist. 


\subsection{Evidence}

San Salvador was the second largest colonial settlement in the region after Guatemala City. By 1824 (shortly after independence), El Salvador had 55 municipalities across the province. ${ }^{115}$ The image below depicts some of the most important municipalities at independence.

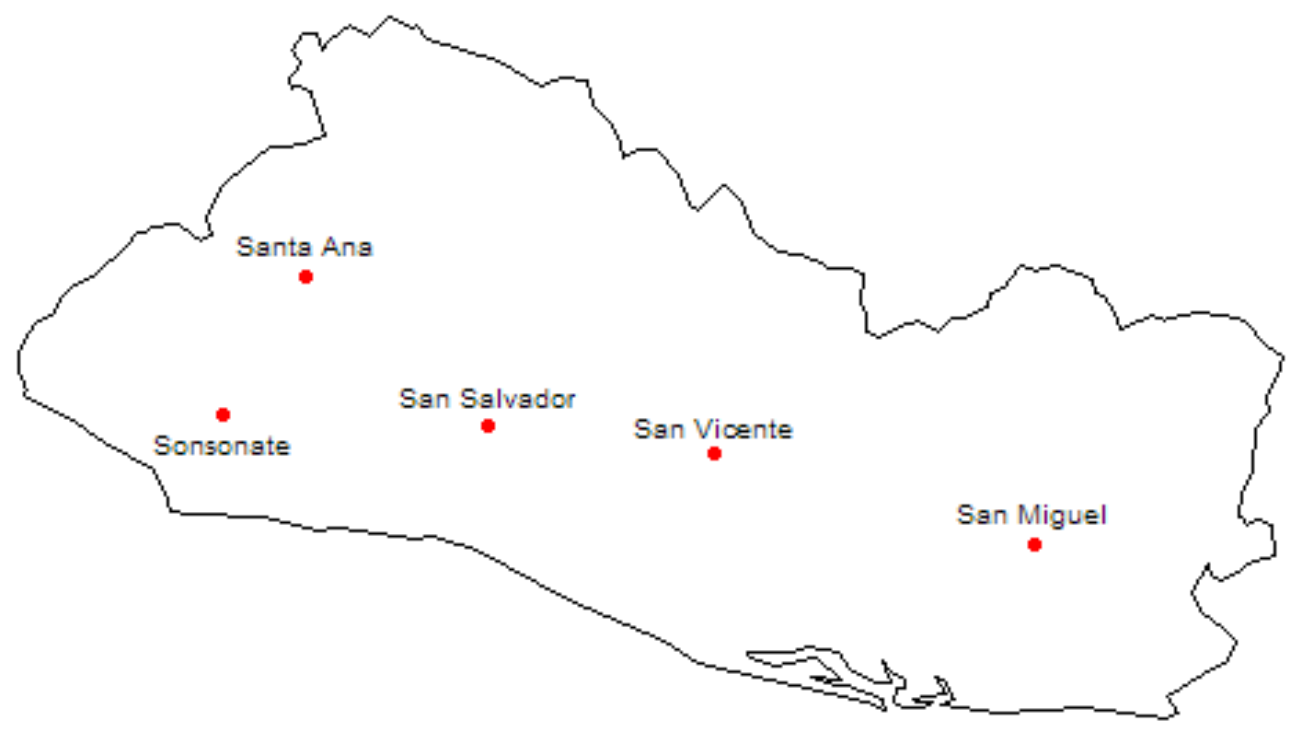

Figure 9: El Salvador - Notable Settlements in 1821

Since independence, El Salvador faced an enormous amount of sustained elite conflict from within and outside of its borders (see image below). From 1824 to 1861 alone, the Salvadoran presidency changed hands 65 times. ${ }^{116}$ Discontented factions did not hesitate to overthrow the chief executive and neighboring provinces were almost always willing 115 (Dym 2006, 275)

${ }^{116}$ (Marure 1895, 141-154; Williams 1994, 202) 
to secure a friendly administration in El Salvador. ${ }^{117}$ The causes of the elite conflict were broadly similar to Guatemala. Municipalities waged war to seize power, settle rivalries, declare their own independent state, switch allegiances (i.e., to Guatemala or to Mexico), and to revolt against taxes or laws they did not agree with. ${ }^{118} 119$ For instance in 1832, during the attempt at a federal union across the isthmus, the state declared its independence from the federal republic while three municipalities (Chalatenango, Metapán, and Sonsonate) invited federal troops to attack San Salvador (the capital) from their municipalities. ${ }^{120}$ Sonsonate in particular chose poorly as San Salvador won the battle and the municipality was stripped of its department capital (and therefore its local market) which it did not gain back for 20 years. ${ }^{121}$ In separate incidents, the municipalities of Sonsonate, San Vicente, and San Miguel wrote letters amongst each other, unbeknown to San Salvador, noting that they were in regular contact with municipalities in Honduras and that the municipalities should keep their options open should they choose to disown the state. ${ }^{122}$

El Salvador was a primary theater of war in a series of battles with all of its neighbors except Costa Rica from independence through the early 20th century. ${ }^{123}$ The majority of El Salvador's external battles were fought with Guatemala and their primary causes were the annexation with Mexico, the attempt at a federal union, and ideological differences (i.e., conservative versus liberal) between caudillos.

\footnotetext{
117(Munro 1918, 104)

118 (Dym 2006, 190; Lauria-Santiago 1999, 122; Munro 1918, 101)

${ }^{119} \mathrm{El}$ Salvador was created out of territory originally belonging to Guatemala.

${ }^{120}$ (Dym 2006, 190)

${ }^{121}$ (Dym 2006, 236)

122(Dym 2006, 238)

${ }^{123}$ (Woodward 1993, 97)
} 


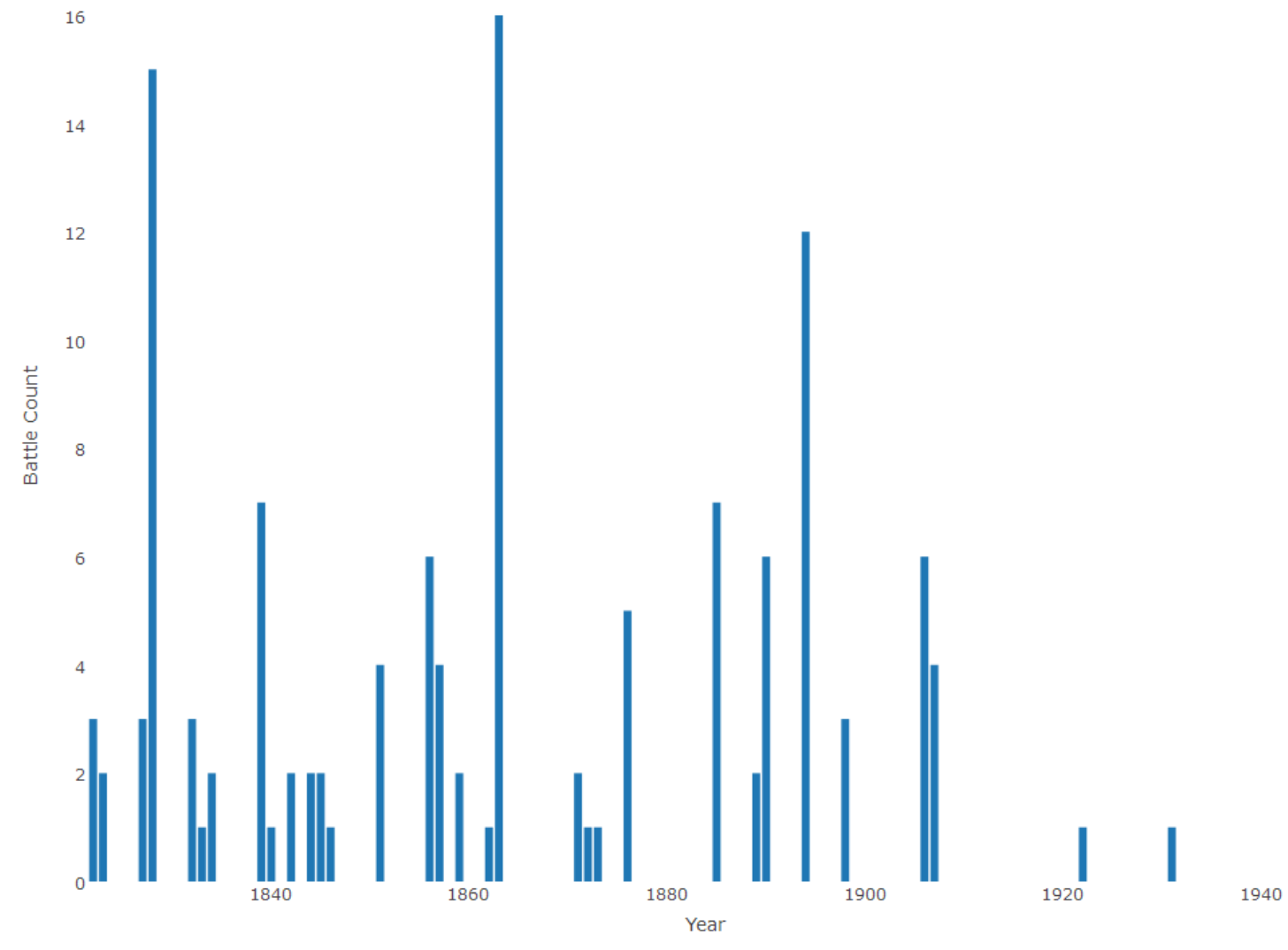

(Maceo 1951; Marure 1895)

Figure 10: El Salvador - Battles Fought Internally and Externally Since 1821

The extent of elite conflict led rulers (who averaged 1.75 years in office from 1824-1861) to prioritize investments in security institutions over the economic institutions which promoted long term development. Unlike Costa Rica and Guatemala, comprehensive Salvadoran government records during the 19th century are relatively scarce (or perhaps non-existent). ${ }^{124}$ Despite missing data, this section pieces together fragmentary government records and qualitative evidence to support the hypothesized causal mechanisms.

Since at least 1840, the army was El Salvador's chief institution (officially formalized

\footnotetext{
${ }^{124}$ San Salvador was completely destroyed in an earthquake in 1854 which likely contributed to this problem.
} 
in 1876) as it consumed the largest amount of government expenditures. ${ }^{125} 126$ In nonwar years, the army received around $27 \%$ of total expenditures, while in war-years, it received between 40 and 50\%, which did not include the money borrowed voluntarily and involuntarily. ${ }^{127}$ The next highest expenditure was servicing the debt (likely correlated to the costs of war), followed by general civil expenditures, and then education (at most $5 \%$ ). This pattern only worsened by the end of the century as rulers discovered the advantages of a strong army in quelling rebellion. ${ }^{128}$ By 1892, the army had an estimated 4,500 members spread throughout all 16 departments while the reserve militia comprised 60,000 men. ${ }^{129}$ The image below overlays El Salvador's state spending on security institutions over the battles it fought.

\footnotetext{
${ }^{125}$ (Lindo-Fuentes 1990, 63)

${ }^{126} \mathrm{El}$ Salvador also had several rural police organizations which later merged into the more commonly known police institution called the National Guard in 1911.

${ }^{127}$ Forced loans were a common occurrence. A Scottish traveler in 1840 was approached by two relatively rich Salvadoran strangers who tried to turn over all their property to him to avoid a 10,000 peso forced loan. (Lindo-Fuentes 1990, 52)

${ }^{128}$ (Lindo-Fuentes 1990, 80)

${ }^{129}$ (Mahoney 2001, 136)
} 


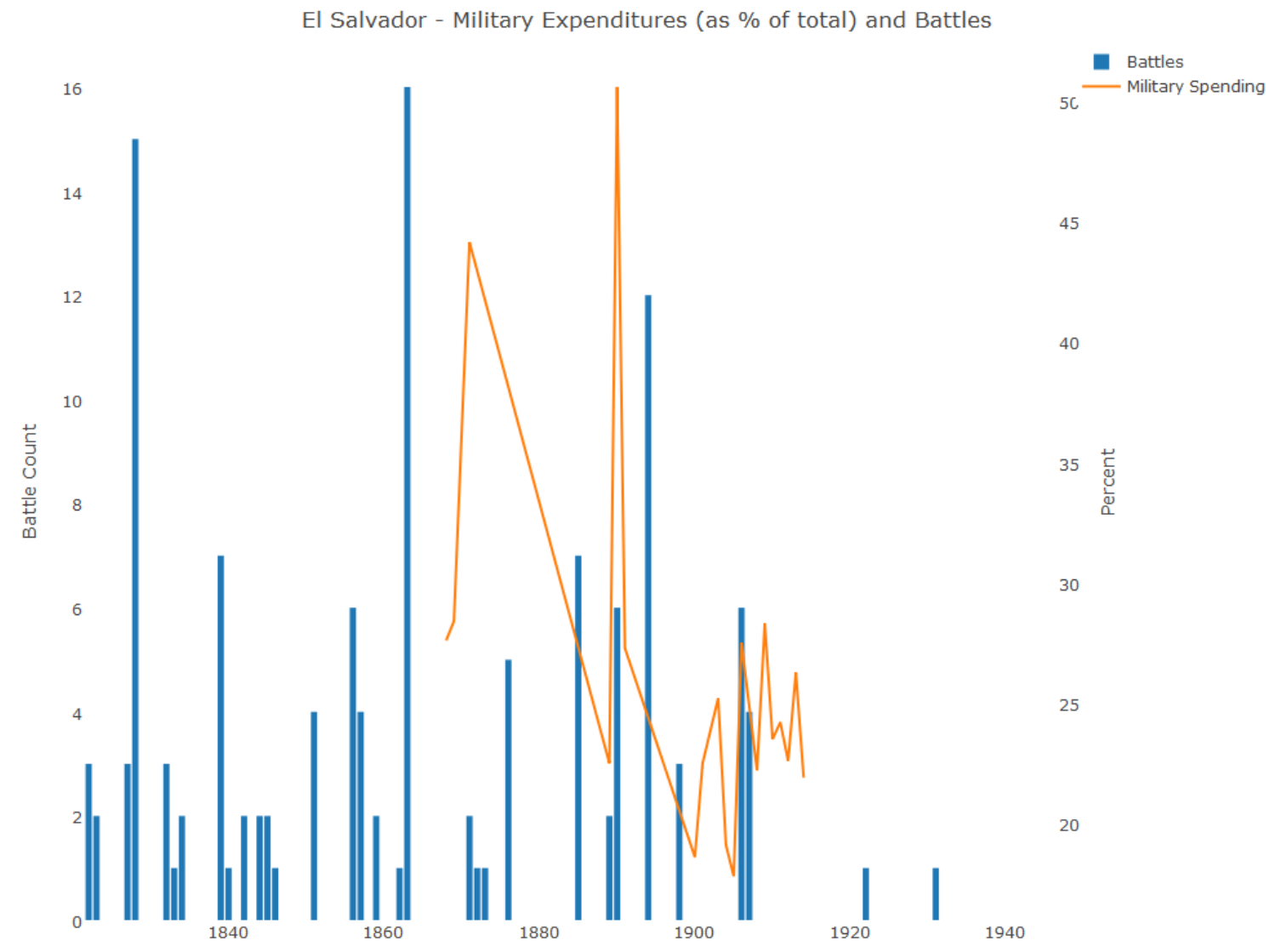

(Maceo 1951)

Figure 11: El Salvador - Battles Fought Internally and Externally Since 1821

Contrasting with Costa Rica and Guatemala, El Salvador placed a much weaker emphasis on institutions that promoted economic development. For instance, El Salvador did not create a development institution akin to the Consulado or the Sociedad Económica that was charged with developing infrastructure and agriculture until it founded the Ministerio de Fomento in 1888 and road improvements were of little priority to the state. ${ }^{130}$ 131 A German traveler noted the roads in El Salvador were terrible year round and

${ }^{130}$ (De Noia 1947, 28)

${ }^{131}$ Fomento is the liberal (and Spanish) term for development. As part of the liberal wave across the isthmus in 1870, all states eventually created a Ministerio de Fomento which all still exist today. States that had existing development institutions like Guatemala and Costa Rica, renamed their respective institutions to Ministerio de Fomento. 
completely impassable during rainy season (roughly six months). ${ }^{132}$ A widening of a mule trail from San Salvador (the capital) to its nearest port (La Libertad) took 10 years. Public works between smaller municipalities were financed and completed by private individuals while during years of conflict, primary roads received no maintenance. ${ }^{133}$ ${ }^{134}$ Education was hardly promoted and schools were often ephemeral institutions that opened and closed at whim. For instance in January 1849, the state newspaper reported that Cuscatlán province had 34 schools, while in June it had 49 , and one year later it had 38. ${ }^{135} 136$ The table below clearly shows very little improvements in the number of students enrolled in schools over a 42 year period despite the population doubling.

Table 9: Number of Schools for Selected Years

\begin{tabular}{cccc}
\hline Year & Schools & Students & Total Population \\
\hline 1850 & 201 & 6,696 & 372,815 \\
1888 & 375 & 21,200 & 687,605 \\
1892 & 585 & 29,427 & 703,000 \\
\hline \multicolumn{4}{c}{ Lindo-Fuentes 1990,69}
\end{tabular}

Table 7 below reinforces the narrative portrayed thus far despite limited primary document availability. We can clearly see that the military and debt spending simply overwhelmed all other categories which is a consequence of the persistent and high levels of conflict.

\footnotetext{
${ }^{132}$ (Lindo-Fuentes 1990, 74)

133 (Lindo-Fuentes 1990, 77)

${ }^{134}$ Roads in Central America required significant upkeep as torrential rains regularly damaged or completely destroyed them. Roads during this time period simply mean either a dirt trail wide enough for a donkey or in special cases, dirt trails wide enough to pull an ox cart.

${ }^{135}$ (Lindo-Fuentes 1990, 68)

${ }^{136} \mathrm{~A}$ German traveler noted that "[El Salvador's] education is still at a very low grade, although there is much good-will on the subject". (Lindo-Fuentes 1990, 68)
} 
Table 10: El Salvador: Expenditures as \% of Total

\begin{tabular}{cccccc}
\hline Year & Military & Debt & Education & Development & Government \\
\hline 1868 & 28 & 13 & 5 & 15 & 2 \\
1869 & 28 & 9 & 6 & 14 & 6 \\
1871 & 44 & 12 & 4 & 10 & - \\
1889 & 23 & 24 & 9 & 9 & 17 \\
1890 & 51 & 17 & 4 & 7 & 7 \\
1891 & 28 & 13 & 5 & 15 & 2 \\
1900 & 19 & 47 & 4 & 3 & 12 \\
1901 & 23 & 42 & 4 & 5 & 12 \\
1902 & - & - & - & - & - \\
1903 & 25 & 32 & 5 & 8 & 13 \\
1904 & 19 & 40 & 6 & 5 & 13 \\
1905 & 18 & 38 & 6 & 8 & 14 \\
1906 & 28 & 34 & 5 & 7 & 12 \\
1907 & - & - & - & - & - \\
1908 & 22 & 37 & 4 & 8 & 14 \\
1909 & 28 & 24 & 4 & 11 & 16 \\
1910 & 24 & 36 & 4 & 8 & 15 \\
1911 & 24 & 28 & 6 & 8 & 15 \\
1912 & 22 & 27 & 6 & 14 & 13 \\
1913 & 26 & 28 & 5 & 9 & 13 \\
1914 & 22 & 25 & 6 & 13 & 16 \\
\hline
\end{tabular}

\subsection{Conclusion}

Despite a lower quality of evidence, this case study documented the theorized mechanisms at work which links the sequence of events from a high number of colonial municipalities to the origins and emphasis on security institutions in El Salvador. The strongest evidence for the first mechanism is the shifting alliances of the municipalities, their rebellions, and their clandestine letters in case they chose to disavow the state in the future suggesting a wide range of diverse preferences. The strongest piece of evidence for the second mechanism is the fragmentary evidence which spans several decades showing that the security institutions received the greatest proportion of state 
resources while development institutions which favored long-run economic growth were comparatively neglected. Much like Guatemala, a continuous threat from rival elites increased Salvadoran rulers' uncertainty over their own political survival which imbued new preferences over institutions such that their spending of state resources heavily biased security over development institutions.

\section{Case Study: Nicaragua}

"Restless men who, not content with the order of things now established, encourage the spirit of localism which blinds those who succumb to it and does not let them see the abyss into which they are about to plunge" ${ }^{137}$ - José León Sandoval (1847), 19th President (Supreme Commander) of Nicaragua

\subsection{Event History Map}

Mirroring the causal graph, the event-history map below depicts the process by which the events are traced in the case study.

Table 11: Event History Map: Nicaragua

\begin{tabular}{lcccc}
\hline Antecedent Condition & $\mathrm{M}_{1}$ & Cause & $\mathrm{M}_{2}$ & Effect \\
\hline $\begin{array}{c}53 \text { colonial } \\
\text { municipalities }\end{array}$ & $\stackrel{\text { High Diverse }}{\underset{\text { Preferences }}{\longrightarrow}}$ & $\begin{array}{c}56 \text { battles } \\
\text { fought }\end{array}$ & $\begin{array}{c}\text { Preferences Over } \\
\text { Security Institutions }\end{array}$ & $\begin{array}{l}\text { Rulers predominantly invest } \\
\text { security institutions = TRUE }\end{array}$
\end{tabular}

\subsection{Expectations}

This paper's theory predicts that the extent of elite conflict leads rulers to be more likely to adopt certain types of institutions over others. The extent of elite conflict is determined

${ }^{137}$ (Burns 1991, 34) 
by the number of royally granted municipalities during the colonial era. To support the argument, I need to show that a high number of municipalities in Nicaragua leads to relatively high levels of elite conflict through my mechanism of diverse preferences. In the post-colonial period, municipalities should behave autonomously and at times, quite belligerent. I also need to show that the high level of elite conflict is a necessary condition for rulers to invest more state resources into security institutions rather than development institutions. Over time, so long as the level of elite conflict remains high, we should see evidence that Nicaragua invests mostly into security institutions while generally neglecting development.

\subsection{Evidence}

Next to Costa Rica, Nicaragua had the lowest number of colonial granted municipalities in Central America despite it having two relatively important conquest cities: León and Granada. ${ }^{138} 139$ By 1824 (shortly after independence), Nicaragua had 53 municipalities across the province. ${ }^{140}$ The image below depicts some of the most important municipalities at independence.

\footnotetext{
${ }^{138}$ The cities were founded in 1524 by the conquistador Francisco Hernández de Córdoba to mark his successful conquests.

139 (Burns 1991, 88)

${ }^{140}$ (Dym 2006, 275)
} 


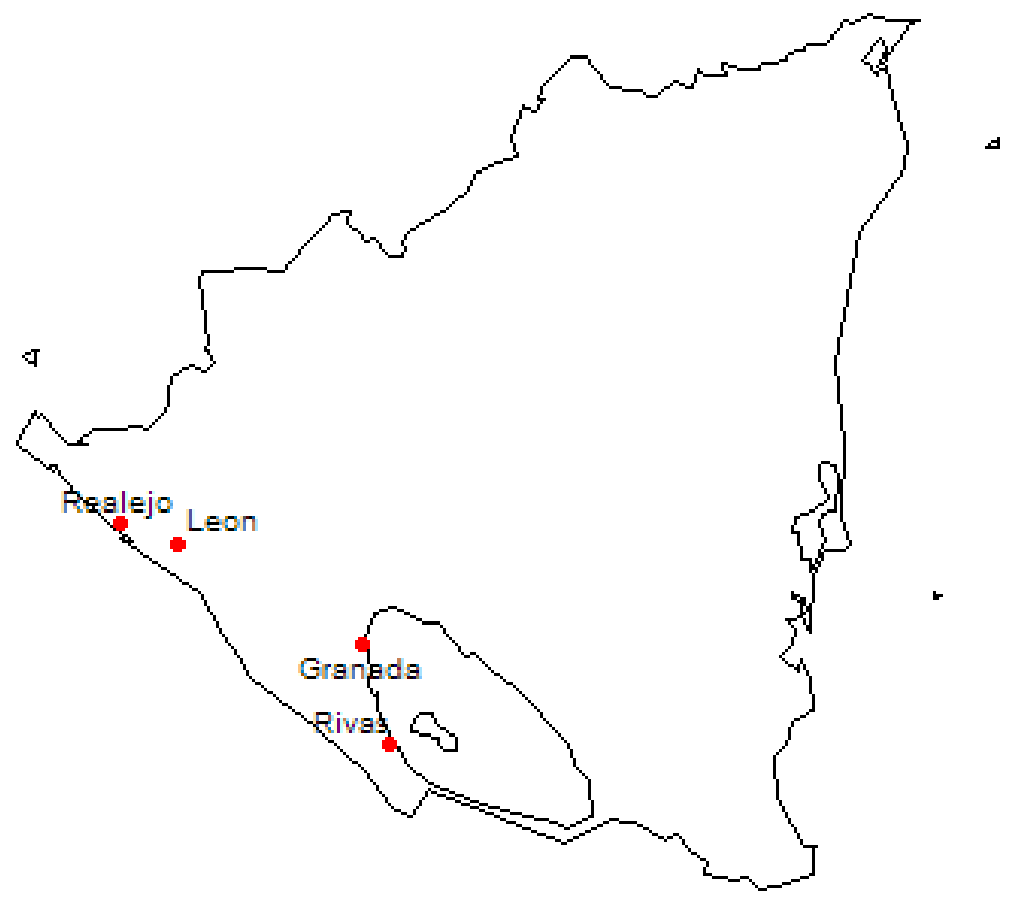

Figure 12: El Salvador - Notable Settlements in 1821

The two largest municipalities (León and Granada) consistently opposed each other and were at intermittent war for decades over who would politically control the nascent Nicaraguan state. The fighting was among the most intense on the isthmus as León was partially destroyed twice in 1824 and $1845 .{ }^{141}$ Costa Rican political leaders looked upon Nicaragua in horror and feared contamination while even Guatemala and El Salvador, both rife with plenty of elite conflict, pointed out Nicaragua as a lesson on the consequences of anarchy. ${ }^{142}$ The conflicts followed similar patterns as elsewhere but had more ideological (liberal versus conservative overtones). ${ }^{143}$ The first battle was fought shortly after independence over the question of annexation. León preferred annexation

\footnotetext{
141(Burns 1991, 93)

${ }^{142}$ (Cruz 2002, 1)

${ }^{143}$ The historical origins of the rivalry between the two largest municipalities is unknown, but their differences extended to the colonial era and were not always based on a particular ideology.
} 
with Mexico, Granada opposed annexation, and neither preferred the other in control of the capital. ${ }^{144} 145$ Although elites in León and Granada dominated a large portion of the conflict in Nicaragua, other municipalities acted in their own interests as well by disavowing the state, attacking the capital, and revolting over taxes. For example in 1833, the municipalities of Managua, Matagalpa, and Masaya disavowed the Nicaraguan supreme commander (president) which compelled León and Granada to unite to quell the three municipalities. Just one year later, Granada and a municipality in El Salvador (Metapán) joined forces in attacking León. ${ }^{146}$ In 1845, multiple municipalities launched intermittent rebellions for four years over the state's monopoly taxes on alcohol which the state refused to rescind. ${ }^{147}$ The consistent warfare exacerbated the autonomy and localism expressed by the municipalities. From 1821 to 1857, the government moved from León to Granada to Masaya to Chinandega to Rivas and then to Managua. At one time in 1823 and in 1824, four different governments located in León, Granada, Managua, and El Viejo claimed legitimacy of the state. ${ }^{148}$ From 1825 to 1854, over 25 chief executives governed but their authority barely stretched beyond the capital. ${ }^{149} 150$

While internal rivalries within Nicaragua were particularly intense, Nicaragua was also involved in several external wars with its neighbors. ${ }^{151}$ One war in particular, despite its severity, brought a notable period of relative calm to Nicaragua. The rivalry between León and Granada led León to recruit American mercenaries to help defeat Granada and seize political power. In June 1855, Walker and 58 Americans arrived in Nicaragua

\footnotetext{
144 (Burns 1991, 15)

${ }^{145}$ León and Granada also held sway over the smaller municipalities within their immediate reach which drew them into conflict as well. Granada exercised control over departments of Granada, Rivas, and part of Matagalpa while León held sway over the departments of Nueva Segovia, Leon, and part of Matagalpa.

146(Dym 2006, 237)

147 (Burns 1991, 47)

148 (Burns 1991, 41)

149 (Burns 1991, 42)

${ }^{150}$ A German traveler in the 1850s carried a recommendation letter from the Nicaraguan President but found it to be worthless. When he asked the Governor of Matagalpa whether the President's recommendation letter made every other unnecessary, he answered, "Ah! the President is a long way off. The nearest authority is always the best!" (Burns 1991, 35)

${ }^{151}$ (Woodward 1993, 95)
} 
and were given command of liberal (León) forces. By October 1855, Walker captured Granada, became commander in chief of Nicaragua, and gained U.S. recognition shortly thereafter. ${ }^{152} 153$ In 1856, the Central American states declared war on Nicaragua and all four countries invaded to overthrow Walker leading to the near complete destruction of Granada and a temporary period of relative calm in Nicaragua.

Nicaragua - Battles

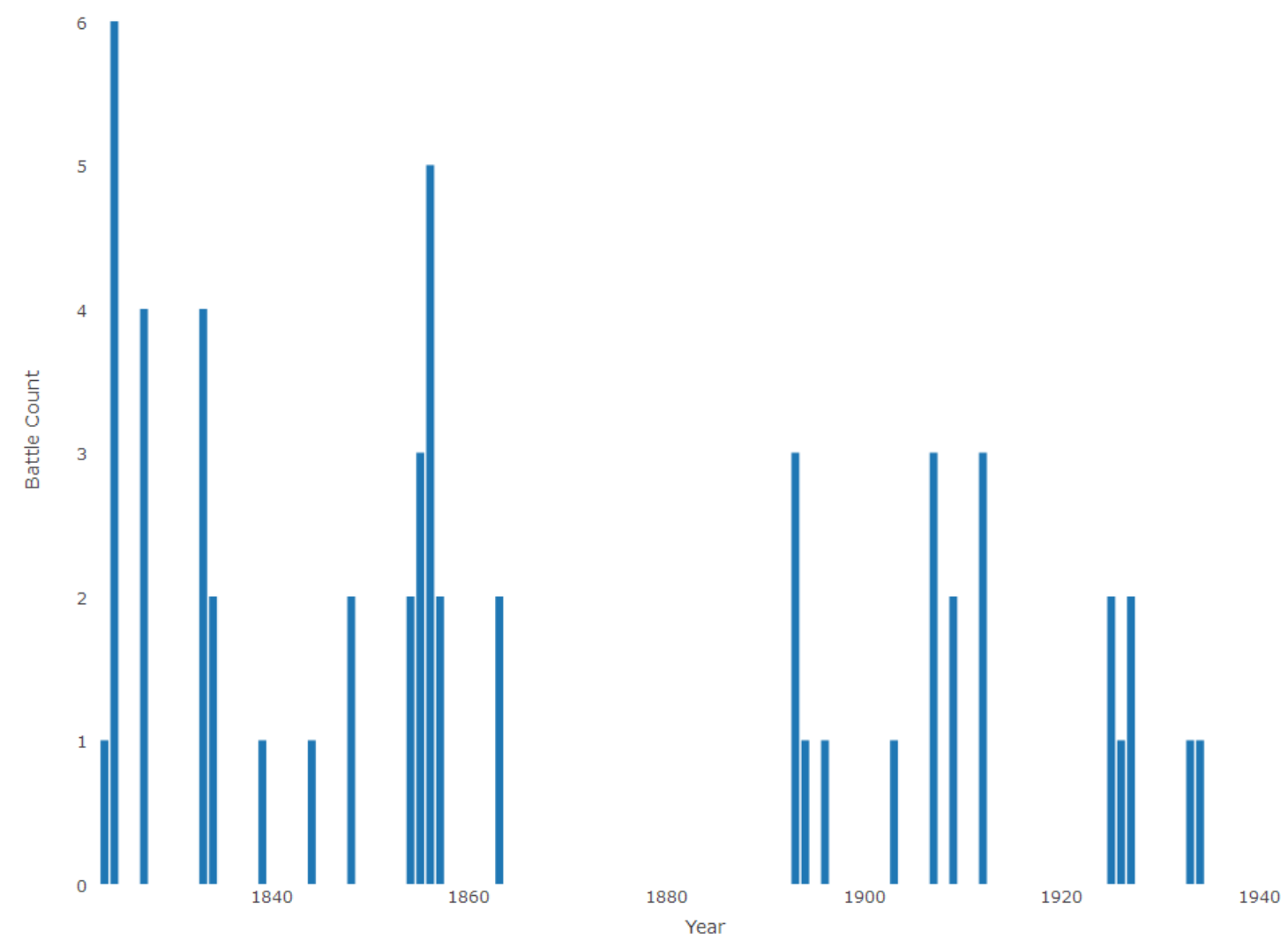

(Barbosa 2007; Marure 1895)

Figure 13: Nicaragua - Battles Fought Internally and Externally Since 1821

Information on the Nicaraguan government's composition and actions is quite scarce during the early 19th century and it is not until the end of the 19th century when José ${ }^{152}$ (Burns 1991, 199)

${ }^{153}$ Walker outmaneuvered the Granada militia as he feigned an attack on the town of Rivas. Granada's forces shifted to defend Rivas which left Granada largely undefended. Granada was taken easily and Walker forced the surrender of Granada's troops by holding hostage their families in Granada. 
Santos Zelaya (1893-1909) seized power that better and more information became available, at least through secondary sources. By 1846, the size of the government was incredibly small, comprising only four positions: the President and ministers for war, treasury, and foreign relations. ${ }^{154}$ Following similar patterns in Guatemala and Costa Rica, only much later, Zelaya also instituted jefes politicos in each department to intervene in municipality autonomy by collecting and distributing state financial resources, enforcing laws, and monitoring municipality activity through the police. ${ }^{155}$

While Nicaragua was engaged in a large number of battles over many decades, we have very little comprehensive statistics regarding the government's expenditures (see table below). Like other Central American republics facing high levels of elite conflict, Nicaragua's military expenditures reportedly remained high, even in peacetime. ${ }^{156}$ From 1845 to 1851 , total government expenditures averaged 250,000 pesos a year while $66 \%$ of this was budgeted to the army. ${ }^{157}$ After the Walker Affair, the Nicaraguan militia shrunk considerably to a force equivalent to its size at independence. ${ }^{158}$ In 1895, Zelaya formally institutionalized the army and while its exact size is not known, it was reportedly among the strongest by the early 20th century. The army was used to not only quell internal rebellions and fight external wars, but the army was also required to arrest labor fugitives and to distribute state resources. ${ }^{159}$ Following Zelaya's arrival and growth of the army, a municipality would never again challenge the sovereignty of the national government through armed opposition. ${ }^{160}$

\footnotetext{
154(Burns 1991, 44)

155 (Mahoney 2001, 182-183)

${ }^{156}$ (Mahoney 2001, 182)

${ }^{157}$ (Cruz 2002, 34)

${ }^{158}$ (Cruz 2002, 54)

159 (Mahoney 2001, 182)

${ }^{160}$ (Mahoney 2001, 183)
} 
Table 12: Nicaragua - Select Years of Government Expenditures

\begin{tabular}{cccc}
\hline Year & Military & Total & $\%$ Total \\
\hline 1845 & 146 & 257 & 57 \\
1851 & 108 & 173 & 62 \\
$1881-2$ & 389 & 3,240 & 12 \\
\hline
\end{tabular}

Thousands of Pesos - (Burns 1991, 56; Cruz 2002, 85)

With respect to economic institutions, the state had little opportunity or resources to devote to them while elite conflict remained high. In May 1853, the state created its own Consulado de Comercio, but disbanded it shortly thereafter (likely due to the William Walker Affair), and then re-created it in April 1858. ${ }^{161}$ Notable investments in development policies and institutions came largely during a period of peace following the Walker Affair. While the reconstruction of Granada consumed notable resources which influenced state spending, roads between Leon, Granada, and the Pacific port at Corinto were improved to support ox carts from 1857 to 1867 where prior to this, all roads were mule trails. ${ }^{162}$ By the late 1880s, Nicaragua's education budget neared 500,000 pesos, up from 4,000 pesos in 1871-1872, and came close to matching the number of schools, teachers, and enrolled students in Costa Rica (the regional leader). ${ }^{163}$ This pattern largely persisted as rulers continued notable investments in the state bureaucracy, $\mathrm{road} /$ rail infrastructure, and communications (i.e., telegraph) infrastructure. ${ }^{164}$ While several important advances were made, the state's focus on development institutions clearly emerged during periods of limited to no elite conflict and on average, never eclipsed spending on security institutions.

${ }^{161}$ (Decreto legislativo de 6 de mayo 1853; Decreto ejecutivo de 16 de abril 1858)

${ }^{162}$ (Cruz 2002, 60; Williams 1994, 81)

163 (Cruz 2002, 151)

164(Mahoney 2001, 183) 
Table 13: Nicaragua - Select Years of Government Expenditures

\begin{tabular}{ccc}
\hline Year & Development & Education \\
\hline $1871-72$ & 0 & 4 \\
$1873-74$ & 39 & - \\
$1875-76$ & 44 & - \\
$1877-78$ & 135 & 61 \\
$1879-82$ & 420 & 111 \\
$1881-82$ & 536 & 185 \\
$1883-84$ & 675 & 338 \\
\hline \multicolumn{2}{l}{ Thousands of Pesos - (Cruz 2002, 88) }
\end{tabular}

\subsection{Conclusion}

This case study documented the theorized mechanisms at work which links the sequence of events from the high number of colonial municipalities to the origins and emphasis on security institutions in Nicaragua. The strongest evidence for the first mechanism is the fact that much like the other Central American republics, the municipalities led multi-year rebellions, seceded, and attempted to seize the capital through armed opposition with no clear uniformity suggesting a high degree of diverse preferences. The strongest evidence for the second mechanism is the limited time series government spending records, the limited government of four ministers and a supreme commander by the mid 19th. A near continuous threat from rival elites increased Nicaraguan rulers' uncertainty over their own political survival and imbued new preferences over institutions such that their spending of state resources heavily biased security over development institutions. 


\section{Case Study: Honduras}

"The higher classes are composed of wealth, education, and refinement and these classes really constitute the governing element and dominate all public action. There is, however, no unity of purpose or action among them. They are divided into numberless factions, each faction representing some individual of dominant intellectual ability, or qualities of leadership, or possession of personal charms to attract or draw other men unto them". ${ }^{165}$ - John Ewing (1914), U.S. Minister (Ambassador) in Tegucigalpa

\subsection{Event History Map}

Mirroring the causal graph, the event-history map below depicts the process by which the events are traced in the case study.

Table 14: Event History Map: Honduras

\begin{tabular}{|c|c|c|c|c|}
\hline Antecedent Conditior & $\mathrm{M}_{1}$ & Cause & $\mathrm{M}_{2}$ & Effect \\
\hline \begin{tabular}{|c|}
57 colonial \\
municipalities
\end{tabular} & $\underset{\text { Preferences }}{\stackrel{\text { High Diverse }}{\longrightarrow}}$ & $\begin{array}{c}170 \text { battles } \\
\text { fought }\end{array}$ & $\underset{\text { Security Institutions }}{\stackrel{\text { Preferences Over }}{\longrightarrow}}$ & $\begin{array}{l}\text { Rulers predominantly invest } \\
\text { security institutions = TRUE }\end{array}$ \\
\hline
\end{tabular}

\subsection{Expectations}

This paper's theory predicts that the extent of elite conflict leads rulers to be more likely to adopt certain types of institutions over others. The extent of elite conflict is determined by the number of colonial municipalities. To support the argument, I need to show that the relatively high number of municipalities in Honduras leads to relatively high levels of elite conflict through the mechanism of diverse preferences. In the post-colonial period, municipalities should behave autonomously and at times, quite belligerent. I also 165 (Euraque 1972, 49) 
need to show that the high level of elite conflict leads rulers to invest more state resources into security institutions rather than development institutions. Over time, so long as the level of elite conflict remains high, we should see evidence that Honduras invests mostly into security institutions while generally neglecting development.

\subsection{Evidence}

By 1824 (shortly after independence), Honduras had 57 municipalities across the province. ${ }^{166}$ The image below depicts some of the most important municipalities at independence.

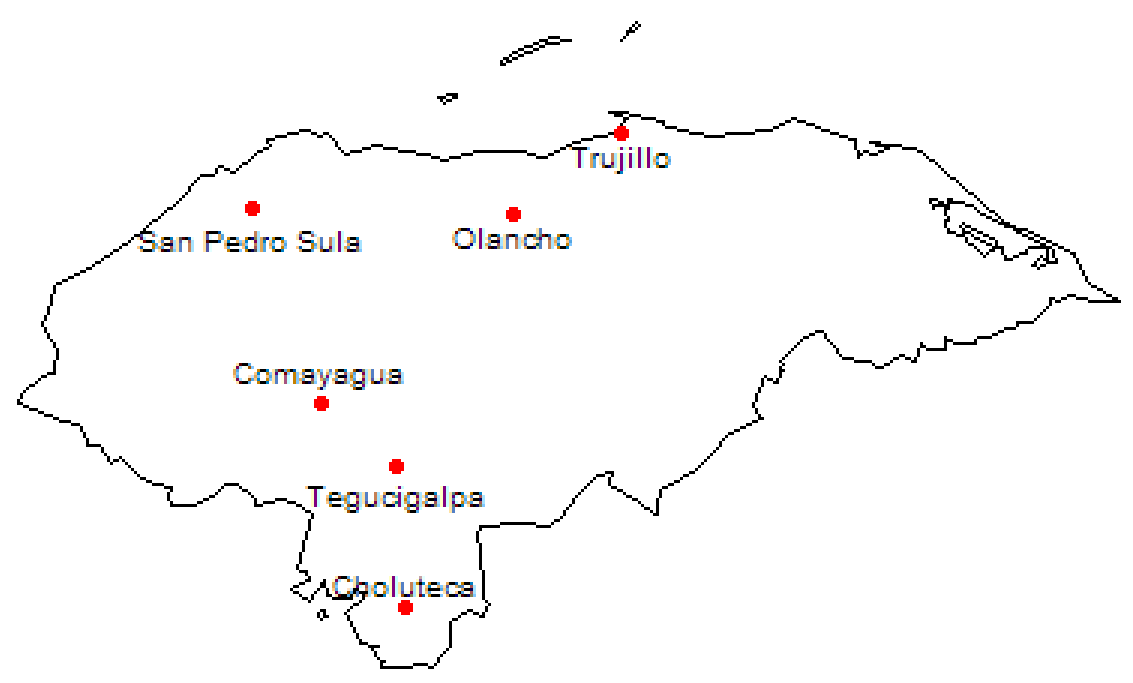

Figure 14: Honduras - Notable Settlements in 1821

Much like the rest of Central America, Honduras' elites fought incessantly over a 166(Dym 2006, 275) 
wide range of issues for nearly 100 years, leaving Honduras with probably the highest levels of elite conflict across the isthmus (see image below). ${ }^{167}$ The plot below is a highly conservative representation as additional data on 77 battles from 1890 to 1939 is omitted due to a lack of individual year specificity. ${ }^{168}$ From 1820 to 1876, Honduran chief executives averaged only about 6.5 months in power as elites struggled for control over the central government by mobilizing guerrilla bands composed of relatives, friends, and alliances with other ambitious politicians. ${ }^{169}$ If the elites succeeded in seizing the capital, the new chief executive formalized his cohorts' appointments within the military structure (e.g., promoting them to colonels, etc) and assigned them to high ranking positions such as governorships. ${ }^{170}$ While most other Central American republics consolidated power in a state capital within a few decades after independence, Honduras took approximately six decades to accomplish the same feat which was a consequence of elites continuously seizing or attempting to seize power. ${ }^{171}$

Municipalities acted in their own interests first and in the state's interest only after deliberation. This phenomenon was most apparent in the rivalry and volume of conflict between the two largest municipalities who held opposing views and were incredibly belligerent toward each other. ${ }^{172}$ This bitter rivalry led to many small battles and shifts in the location of the state's capital between Comayagua (the colonial conquest city) and Tegucigalpa from 1824 to $1880 .{ }^{173}$ One of their first conflicts was over the question of Mexican annexation where Comayagua preferred annexation while Tegucigalpa did not, prompting Comayagua to threaten war. ${ }^{174}$ In 1826 , the Tegucigalpa municipality received

\footnotetext{
${ }^{167}$ Given the available data, there is still some uncertainty regarding the true extent of elite conflict across Central America as the evidence presented in each case study is certainly conservative in its estimates of battles. While Honduras likely had the most, I am erring on some uncertainty.

${ }^{168}$ These 77 battles are recorded in ten year intervals only. (Chávez 1972, 457)

${ }^{169}$ (Euraque 1972, 2)

${ }^{170}$ (Federal Research Division 1995, 213)

${ }^{171}$ For a table of changes in state capitals by year and duration, please see: (Dym 2006, 231)

${ }^{172}$ This rivalry extended back to the late 17th century yet the two municipalities never once went to war with each other under Spanish rule.

${ }^{173}$ (Dym 2006, 231)

${ }^{174}$ (Stokes 1950, 35)
} 
a letter from Comayagua (the capital at the time) stating that there were assassination attempts on the Honduran president and there were concerns over the fragility of the federal union. In response, Tegucigalpa sent a letter to Comayagua declaring that they had the right to decide where to place their allegiance and how much aid they would offer, but they agreed to send 50 unarmed militia. ${ }^{175}$ In 1828, a municipality in Olancho, which was participating in an uprising against the state, wrote a letter to Tegucigalpa (the capital at the time) stating that it did not believe Tegucigalpa had any legitimate authority and that legitimate authority only rested within the municipalities. ${ }^{176}$ In 1838 , Tegucigalpa declared itself separate from Honduras and placed itself under Nicaragua's protection until Comayagua (the capital at the time) acceded to its demands. ${ }^{177} 178$ In 1839, a municipality (Pespire) declared that it was no longer apart of the Choluteca department and attached itself to Tegucigalpa (not the capital at the time). Tegucigalpa welcomed the act and asked the local governor to thank the town and to protect it as much as possible (from Choluteca and perhaps Comayagua). ${ }^{179}$

\footnotetext{
175 (Dym 2006, 236)

${ }^{176}$ (Dym 2006, 234)

177 (Dym 2006, 239)

${ }^{178}$ The municipality in Tegucigalpa sought to be its own state following independence after it declared its independence from Spain.

${ }^{179}$ (Dym 2006, 237)
} 


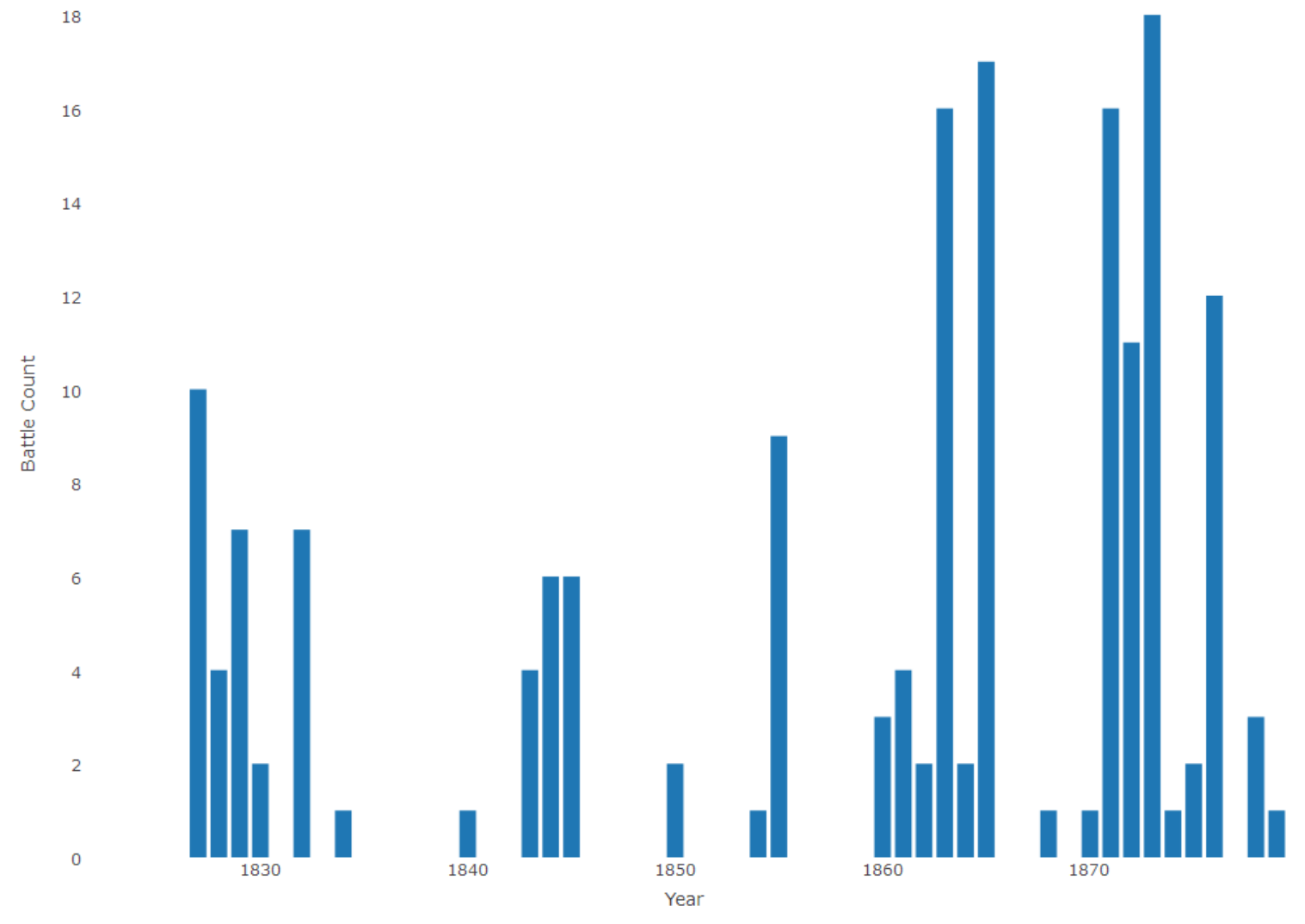

(Chávez 1972; Marure 1895)

Figure 15: Honduras - Battles Fought Internally and Externally Since 1821

While there are few statistics available about the actions and priorities of the Honduran government during the early 19th century (see table below), fragmentary evidence suggests that the government's resources were primarily consumed paying for the army first, and then the large debt which was partly a consequence of the extensive fighting in the country. ${ }^{180}$ The army in Honduras remained a decentralized militia, where militia lists were kept in each department from which names could be drawn in an emergency, until it was formalized in the 1930s. ${ }^{181}$ The first chief executive who initiated and achieved real progress in exerting control over rebellious municipalities was Marco Aurelio Soto ${ }^{180}$ (Euraque 1972, 49)

${ }^{181}$ (Ropp 1974, 506) 
(1876-83). ${ }^{182}$ While some of Soto's success was due to his policies that limited municipality autonomy, the shadow of power lay with Guatemala, the region's most powerful country who placed Soto in power and guaranteed his rule. ${ }^{183}$ For instance, one of Soto's first acts was to increase state spending on the militia, to create Honduras' first police force in the capital, to confiscate as many weapons as possible, and to require all men to serve in the militia with some exception. ${ }^{184}$

Table 15: Honduras - Select Years of War Department Budget (as \% of total)

\begin{tabular}{cc}
\hline Year & War Department \% \\
\hline 1881 & 51 \\
1892 & 26 \\
1894 & 31 \\
1900 & 34 \\
1901 & 42 \\
1902 & 37 \\
$1903-4$ & 36 \\
$1904-5$ & 38
\end{tabular}

(Bureau of the American Republics 1896, 62; Euraque 1972, 49; Mahoney 2001, 168)

Although Soto and subsequent rulers placed some emphasis on development institutions and policies, they were underfunded and emerged the latest relative to Honduras' neighbors on the isthmus. For example, Soto created a national bank, built post offices, expanded road construction, and installed the first telegraph and telephone system. ${ }^{185}$ However, an important national level economic institution, the Ministerio de Fomento was not created until it was codified into the 1936 constitution, some 60 years after its neighbors. ${ }^{186}$

\footnotetext{
${ }^{182}$ (Stokes 1950, 42)

${ }^{183}$ Barrios, then the ruler of Guatemala, only had to hint at invasion to force the current ruler to step down in favor of Soto.

${ }^{184}$ (Mahoney 2001, 168)

185 (Mahoney 2001, 168)

${ }^{186}$ (Stokes 1950, 183)
} 
Available government spending records show that for at least one year of Soto's rule, $51 \%$ of the budget alone went to security institutions. ${ }^{187}$ Given that the debt often consumed the next highest proportion of spending followed by government operating expenses, there was simply little resources available to devote to economic institutions with such levels of elite conflict. However, when elite conflict was extremely low, the Ministerio de Fomento was allotted one million more U.S. dollars than any other state ministry during the biennial budget from 1941 to 1942 (only two battles were recorded from 1940 to 1949). ${ }^{188} 189$

\subsection{Conclusion}

This case study documented the theorized mechanisms at work which links the sequence of events from the high number of colonial municipalities to the origins and emphasis on security institutions in Honduras. The strongest evidence for the first mechanism is the fact that much like the other Central American republics, the municipalities led rebellions, seceded, altered their allegiances, and attempted to seize the capital through armed opposition with no clear uniformity suggesting a high degree of diverse preferences. The strongest evidence for the second mechanism is the limited time series government spending records and the average 6.5 month survival rate of chief executives from 1820 to 1876. A near continuous threat from rival elites increased Honduran ruler's uncertainty over their own political survival and imbued new preferences over institutions such that their spending of state resources heavily biased security over development institutions.

\footnotetext{
${ }^{187}$ Specific yearly data on elite conflict is missing in 1881 , but from $1870-1879$, Honduras experienced the greatest volume of elite conflict (64), and likely explains the significant spending on security institutions.

${ }^{188}$ I do not have any additional statistics available.

${ }^{189}$ (Chávez 1972, 457; Stokes 1950, 183)
} 


\section{Implications}

While the claim that institutions matter was settled long ago in the early 1990s, many scholars have since transitioned to explaining a far less understood component of institutions: their origins. ${ }^{190}$ Although this research is certainly not the first to claim that elite conflict plays a key role in the origins of institutions, it is the first that I am aware of, that explains the origins of institutions in Central America through this lens. This research contributes to the broader literature on the origins of institutions by illustrating the conditions and mechanisms under which institutions emerge from violent conflict amongst social groups. Instead of bargaining and forming ruling coalitions to mitigate social group conflict which is one general path used in explaining the origins of institutions in other states, rulers in 19th century Central America sought no such option underscoring the variation in the way we think about the origins of institutions. This research also contributes to our knowledge by examining the origins of institutions in a setting (Central America) and time period (19th century) which is relatively underdeveloped as compared to the post-colonial institutional analysis in the post-World War II era.

${ }^{190}$ (Pierson 2000; Thelen 1999) 


\section{Appendix A: Rival Hypotheses}

This section creates general hypotheses for the alternative explanations which rival this paper's own and subjects them to moderately rigorous hoop tests which are used to exclude rival explanations. A hoop test requires that a given piece of evidence must be present within a case for the survival of a hypothesis about that case. ${ }^{191}$ Evidence is presented under that the assumption that it is required for the alternative hypothesized causal sequence to hold linking $\mathrm{X}$ to $\mathrm{Y}$.

\subsection{Ideology}

$H_{5}$ : As liberal rulers seized power from conservatives across the isthmus after 1870, given their ideology, they biased their investments toward economic and development institutions over security institutions. ${ }^{192}$

\subsubsection{Hypothesis Testing}

There are at least three pieces of evidence that are necessary for the causal sequence identified in $H_{5}$ to be true. First, liberal rulers are required to seize power. Second, liberal ideology is a necessary condition for biases towards economic and development preferences over institutions. Third, state spending biases economic and development institutions over security institutions.

\subsubsection{Evidence \#1}

As discussed earlier in the analysis, it is true that liberal caudillos swept the isthmus generally after 1870 with the exception of Nicaragua which transitioned from conservative

${ }^{191}$ (Mahoney and Goertz 2012, 93)

${ }^{192}$ To be clear, no research which invokes ideology as an argument also poses a hypothesis. I do not believe this is a caricature of the argument however. 
to liberal rule in $1893 .{ }^{193}$

\subsubsection{Evidence \#2}

"I urgently needed this trip to correct my ideas and to be useful to my country... I will return to preach to my fellow countrymen what we Central Americans are and what we can become.". 194 - Letter from Gerardo Barrios in Rome, 1853 (Salvadoran liberal dictator 1859-1863)

While some evidence suggests that liberal ideology shaped ruler preferences over institutions, far more evidence disconfirms its logic. ${ }^{195}$ As discussed in the beginning of this paper, the basic logic of the argument is that ideology formed ruler preferences over institutions and liberal rulers were inherently more focused on development and economic institutions than conservative rulers. This is in part how Costa Rica's development is explained by those invoking ideology - all their rulers were liberals. Therefore, evidence of conservative rulers pursuing development strategies, or, liberal rulers pursuing security strategies, should cast notable doubt on this mechanism and such evidence is abundant. Indeed it is a myth that all of Costa Rica's leaders were liberal, that conservative regimes did not pursue development and economic institutions, and that liberal rulers in every country except for Costa Rica invested more resources in development institutions over security institutions. ${ }^{196}$

\subsubsection{Evidence \#3}

Given liberal preferences over development institutions, we should see a far greater emphasis in spending on economic and development institutions over security institutions. The Guatemalan and El Salvadoran case studies document yearly military and/or

\footnotetext{
193 (Woodward 1993, 348)

${ }^{194}$ (Lindo-Fuentes 1990, 82)

${ }^{195}$ (McCreery 1994, 171)

${ }^{196}$ (Bulmer-Thomas 1987, 3; Cruz 2002, 150; Woodward 1993, 229)
} 
development spending during the liberal transition across the isthmus which shows that rulers still prioritized security over development institutions. Taking all evidence collectively, this suggests that the hypothesized causal sequence and outcome is not true.

\subsubsection{Results}

The table below depicts the results of the hypothesis testing showing that the hypothesis passed the first hoop test, but failed its subsequent tests which eliminates the hypothesis from consideration.

Table 16: H5 - Hypothesis Testing Summary

\begin{tabular}{lc}
\hline Necessary Evidence & Hoop Test \\
\hline Liberal Ruler Seizes Power Post 1870 & $\checkmark$ \\
Ideology Forms Preferences Over Institutions & - \\
State Spending Biases Economic over Security Institutions & - \\
\hline
\end{tabular}




\subsection{Export Agriculture}

$H_{6}$ : As new agricultural exports such as coffee and bananas exceeded traditional exports, elites used the state to create institutions conducive to large scale export agriculture. ${ }^{197}$

\subsubsection{Hypothesis Testing}

There are at least three pieces of evidence that are necessary for the causal sequence identified in $\mathrm{H}_{6}$ to be true. First, new agricultural exports must exceed traditional exports. Second, the newly realized economy must form new preferences over institutions within the economic and merchant elite. Third, the economic and merchant elite leverage state power to create institutions favoring large scale export agriculture.

\subsubsection{Evidence \#1}

It is uncontroversial that export agriculture exceeded traditional exports in every country across the isthmus around the same time as the liberal revolutions of 1871 except for Costa Rica and Honduras. Costa Rica was the first mover in the region and hit this benchmark decades before its neighbors. ${ }^{198}$ Honduras' banana exports surpassed its mining exports by the early 1900s. ${ }^{199}$

\subsubsection{Evidence \#2}

The historical record provides some convincing evidence that the economy does seem to form new preferences over institutions and even regimes (the transition to liberalism) among the elites in part because many events happen rapidly and sequentially after another. The evidence suggests that, liberals seize power, export agriculture skyrockets,

\footnotetext{
${ }^{197}$ To be clear, no research which invokes the export agriculture as an argument also poses a hypothesis. I do not believe this is a caricature of the argument however.

${ }^{198}$ (Williams 1994, 221)

${ }^{199}$ (Euraque 1972, 5)
} 
economic policies and development institutions favoring large scale export are created, and the existing and now formidable security institutions are transitioned toward policing labor as elites find it more in their favor to make money than to seize the capital. As mentioned earlier, there are three very large issues associated with this claim: (1) it implies that elites had far more control over the state than they did (discussed earlier), (2) the economy shaped elite beliefs uniformly when in fact considerable inter-elite conflict existed, and (3) it implies uniform outcomes when outliers like Costa Rica and Honduras stand in stark contrast to states like Guatemala and El Salvador. Given these large inconsistencies, this mechanism cannot be working as hypothesized nor can it be a necessary condition.

\subsubsection{Evidence \#3}

Underlying the economic argument is the fact that many rulers were also personally involved in some way with export agriculture which is why rulers created institutions favorable to export agriculture. As mentioned earlier, it is now generally accepted that the elites had far less influence over the state than previously thought. For instance, during Rafael Zaldívar's liberal rule in El Salvador (1876 to 1885), he was not a coffee planter and he had an antagonistic relationship with many of the coffee families. Zaldívar raised import taxes on the elites from $20 \%$ to $50 \%$ in 1876 and subsequently increased then to $70 \%$ in 1880 which accounted for approximately $60 \%$ of the government's total revenue (no small amount). ${ }^{200}$ The sale of state and communal lands in Guatemala and El Salvador, two states known for severe land concentration among the elite, was not explicitly designed to only favor the elite. ${ }^{201}$ Many peasants and rural middle class acquired land while its concentration among the elite was a consequence of market forces as elites had enough wealth to purchase these small plots over many years. ${ }^{202}$ Taking all

\footnotetext{
${ }^{200}$ (Mahoney 2001, 125)

201 (Lauria-Santiago 1999, 164; McCreery 1994, 197)

${ }^{202}$ Growing coffee was a costly endeavor which would not yield any profits for at least five years. By the time many small farmers joined the coffee export business, they could not compete given the current
} 
evidence collectively, this suggests that the hypothesized causal sequence and outcome is not true.

\subsubsection{Results}

The table below depicts the results of the hypothesis testing showing that the hypothesis passed the first hoop test, but failed its subsequent tests which eliminates the hypothesis from consideration.

Table 17: H6 - Hypothesis Testing Summary

\begin{tabular}{lc}
\hline Necessary Evidence & Hoop Test \\
\hline Coffee/Bananas Exceed Traditional Export Value & $\checkmark$ \\
Economy Forms Preferences Over Institutions & - \\
Institutions Favoring Economic Elites Created & - \\
\hline
\end{tabular}

processing quality demanded by the world market. Consequently, many farmers chose to sell their lands to larger farms which led to the concentration of land among the elites in many states. 


\section{Bibliography}

Acemoglu, Daron, Simon Johnson, and James A. Robinson. The colonial origins of comparative development: An empirical investigation. No. w7771. National bureau of economic research, 2000.

Acemoglu, Daron, Simon Johnson, and James A. Robinson. Reversal of fortune: Geography and institutions in the making of the modern world income distribution. No. w8460. National bureau of economic research, 2001.

Barbosa, F. "Síntesis de la historia militar de Nicaragua: de las guerras intertribales precolombinas al ejército de Nicaragua." (2007).

Bennett, Andrew, and Jeffrey T. Checkel, eds. Process tracing. Cambridge University Press, 2014

Boone, Catherine. Political topographies of the African state: Territorial authority and institutional choice. Cambridge University Press, 2003.

Bulmer-Thomas, Victor. The political economy of Central America since 1920. No. 63. CUP Archive, 1987.

Burns, E. Bradford. Patriarch and folk: the emergence of Nicaragua, 1798-1858. Harvard University Press, 1991.

Bureau of American Republics. Hand book of Honduras. Library of Congress, 1896.

Carballo, José Luis Vega. Orden y progreso: la formación del Estado nacional en Costa Rica. Vol. 4. Instituto Centroamericano de Administración Pública, 1981.

Chávez, Filander Díaz. Sociología de la desintegración regional. No. 1. Universidad Nacional Autónoma de Honduras, Dirección de Extensión Universitaria, 1972. 
Cruz Jr, Arturo J. Nicaragua's Conservative Republic, 1858-93. Springer, 2002.

De Noia, John. A guide to the official publications of the other American republics. Library of Congress, 1947.

Dym, Jordana. From sovereign villages to national states: city, state, and federation in Central America, 1759-1839. UNM Press, 2006.

Easterly, William, and Ross Levine. "Tropics, germs, and crops: how endowments influence economic development." Journal of monetary economics 50, no. 1 (2003): 3-39.

Elliott, John Huxtable. Empires of the Atlantic world: Britain and Spain in America, 1492-1830. Yale University Press, 2007.

Euraque, Darío A. Reinterpreting the Banana Republic: region and state in Honduras, 1870-1972. Univ of North Carolina Press, 1996.

Finnegan, William. "The invisible war." 6th of February 12, no. 4 (1999): 27-29.

Gallup, John Luke, Jeffrey D. Sachs, and Andrew D. Mellinger. "Geography and economic development." International regional science review 22, no. 2 (1999): 179-232.

Geddes, Barbara. Politician's dilemma: building state capacity in Latin America. No. 25. Univ of California Press, 1994.

Jonas, Susanne. The battle for Guatemala: Rebels, death squads, and US power. No. 5 . Westview Pr, 1991.

Lauria-Santiago, Aldo. An Agrarian Republic: Commercial Agriculture and the Politics of Peasant Communities in El Salvador, 1823âĂŞ1914. University of Pittsburgh Pre, 1999.

Levi, Margaret. Of rule and revenue. Vol. 13. Univ of California Press, 1989. 
Lindo-Fuentes, Hector. Weak foundations: The economy of El Salvador in the nineteenth century. University of California Press, 1990.

Loría, Rafael Obregón. Conflictos militares y políticos de Costa Rica. Impr. La Nación, 1951.

Maddison, Angus. "Statistics on world population, GDP and per capita GDP, 1-2008 AD." Historical Statistics (2010): 1-36.

Mahoney, James. The legacies of liberalism: Path dependence and political regimes in Central America. JHU Press, 2001.

Mahoney, James. Colonialism and postcolonial development: Spanish America in comparative perspective. Cambridge University Press, 2010.

Mahoney, James, and Gary Goertz. "A tale of two cultures: Contrasting quantitative and qualitative research." Political analysis (2006): 227-249.

Marure, Alejandro. Efemérides de los hechos notables acaecidos en la república de Centro-América, desde el año de 1821 hasta el de 1842: seguidas de varios catálogos de los presidentes de la república, jefes de estado, etc. Tipografía nacional, 1895.

McCreery, David. Rural Guatemala, 1760-1940. Stanford University Press, 1994.

Merrill, Tim. Honduras a country study. Library of Congress, 1993.

Munro, Dana C., and David Kinley. "The Five Republics of Central America." (1918): $127-127$.

North, Douglass Cecil. Structure and change in economic history. Norton, 1981.

Ovares, Esteban Corella. "El gasto militar del Estado costarricense, 1821-1870." Diálogos Revista Electrónica de Historia 18, no. 1. 
Paige, Jeffery M. Coffee and power: Revolution and the rise of democracy in Central America. Harvard University Press, 1998.

Pierson, Paul. "The limits of design: Explaining institutional origins and change." Governance 13, no. 4 (2000): 475-499.

Perez-Brignoli, Hector. A brief history of Central America. Univ of California Press, 1989.

Przeworski, Adam. "Institutions matter?." Government and opposition 39, no. 4 (2004): $527-540$.

Rodrik, Dani, Arvind Subramanian, and Francesco Trebbi. "Institutions rule: the primacy of institutions over geography and integration in economic development." Journal of economic growth 9, no. 2 (2004): 131-165.

Ropp, Steve C. "The Honduran Army in the Sociopolitical Evolution of the Honduran State." The Americas 30, no. 04 (1974): 504-528.

Slater, Dan. Ordering power: Contentious politics and authoritarian leviathans in Southeast Asia. Cambridge University Press, 2010.

Sokoloff, Kenneth L., and Stanley L. Engerman. "History lessons: Institutions, factors endowments, and paths of development in the new world." The Journal of Economic Perspectives 14, no. 3 (2000): 217-232.

Stokes, William Sylvane. Honduras: an area study in government. Madison: University of Wisconsin Press, 1950.

Thelen, Kathleen. "Historical institutionalism in comparative politics." Annual review of political science 2, no. 1 (1999): 369-404.

Torres Rivas, Edelberto. "History and Society in Central America, trans." (1993). 
Waldner, David. State building and late development. Cornell University Press, 1999.

Waldner, David. "5 What makes process tracing good?." Process Tracing (2014): 126.

Waldner, David. "Process tracing and qualitative causal inference." Security Studies 24, no. 2 (2015): 239-250.

Waldner, David. "Tracing the Process of Process Tracing Methods." In: Francesco Cavatorta and Janine Clark. Doing Political Science Research in the Middle East and North Africa: Methodological and Ethical Challenges. Oxford University Press. Forthcoming.

Walter, Knut. Trade and development in an export economy: the case of El Salvador, 1870-1914. 1977.

Williams, Robert Gregory. States and social evolution: Coffee and the rise of national governments in Central America. UNC Press Books, 1994.

Woodward, Ralph Lee. Class privilege and economic development: the Consulado de Comercio of Guatemala, 1793-1871. Vol. 48. University of North Carolina Press, 1966.

Woodward Jr, Ralph Lee. Rafael Carrera and the Emergence of the Republic of Guatemala, 1821-1871. University of Georgia Press, 2012.

Wortman, Miles L. Government and society in Central America, 1680-1840. Columbia University Press, 1982.

Yashar, Deborah J. Demanding democracy: Reform and reaction in Costa Rica and Guatemala, 1870s-1950s. Stanford University Press, 1997. 